\title{
NOSE TO BACK: COMPATIBILITY OF NASAL CHONDROCYTES WITH ENVIRONMENTAL CONDITIONS MIMICKING A DEGENERATED INTERVERTEBRAL DISC
}

\author{
M.H.P. Gay ${ }^{1,2,}$, A. Mehrkens, ${ }^{1,}$, M. Rittmann ${ }^{1}$, M. Haug ${ }^{3}$, A. Barbero ${ }^{2, *}$, I. Martin ${ }^{2}$ and S. Schaeren ${ }^{1}$ \\ ${ }^{1}$ Department of Spinal Surgery, University Hospital Basel, Switzerland \\ ${ }^{2}$ Department of Biomedicine, University of Basel, University Hospital of Basel, Switzerland \\ ${ }^{3}$ Department of Plastic Surgery, University Hospital Basel, Switzerland \\ $\S$ These authors contributed equally
}

\begin{abstract}
Nasal chondrocytes (NCs) have gained increased recognition for cartilage tissue regeneration. To assess NCs as a source for cell therapy treatment of intervertebral disc (IVD) degeneration, tissue-forming properties of NCs under physiological conditions mimicking the degenerated IVD were compared to those of mesenchymal stromal cells (MSCs) and articular chondrocytes (ACs), two cell sources presently used in clinical trials. Cells were cultured in a combination of low glucose, hypoxia, acidity and inflammation for $28 \mathrm{~d}$. Depending on the conditions, cells were either cultured in the absence of instructive growth factors or underwent chondrogenic instructional priming by addition of transforming growth factor $\beta 1$ (TGF $\beta 1$ ) for the first $7 \mathrm{~d}$. Histology, immunohistochemistry, biochemistry, enzyme-linked immunosorbent assay (ELISA) and quantitative real-time reverse transcriptase-polymerase chain reaction (qRT-PCR) analyses demonstrated limited cell maintenance and accumulation of cartilaginous extracellular matrix for MSCs in IVD conditions. ACs maintained a steady accumulation of glycosaminoglycans (GAGs) throughout all non-acidic conditions, with and without priming, but could not synthesise type II collagen (Col2). NCs accumulated both GAGs and Col2 in all non-acidic conditions, independent of priming, whereas MSCs strongly diminished their GAG and Col2 accumulation in an inflamed environment. Supplementation with inflammatory cytokines or an acidic environment affected NCs to a lower extent than ACs or MSCs. The data, overall indicating that in an inflamed IVD environment NCs were superior to ACs and MSCs, encourage further assessment of NCs for treatment of degenerative disc disease.
\end{abstract}

Keywords: Nasal chondrocytes, articular chondrocytes, mesenchymal stromal cells, intervertebral disc, disc degeneration, cell therapy for disc degeneration, in vitro modelling of degenerated disc disease, tissue engineering, inflammation.

*Address for correspondence: Andrea Barbero, University of Basel, Hebelstrasse 20, 4031 Basel, Switzerland. Telephone number: +41 612652379 Email: andrea.barbero@usb.ch

Copyright policy: This article is distributed in accordance with Creative Commons Attribution Licence (http://creativecommons.org/licenses/by-sa/4.0/).

\section{Introduction}

Lower back pain affects more than 600 million people globally, being the leading disability worldwide (Vos et al., 2012). Intervertebral disc (IVD) degeneration is the most common cause of specific lower back pain (de Schepper et al., 2010; Luoma et al., 2000). The IVD is a symphysis between two vertebral bodies and is the largest non-vascularised structure in the human body. It consists of a central hydrophilic proteoglycan-rich gelatinous core, the nucleus pulposus (NP), which is surrounded by a collagenous ring, the anulus fibrosus. The disc is separated from the vertebrae by a superior and inferior cartilage endplate (Roberts et al., 2006). Degenerative disc disease (DDD) is caused by an imbalance of anabolic and catabolic processes in NP cells, leading to a loss of extracellular matrix (ECM) and its dehydration (Sivan et al., 2014). This change promotes altered biomechanical loading and provokes inflammation, as well as structural damage to the annulus fibrous, which in turn can lead to pain (Adams and Roughley, 2006). Despite known outcomes, approaches to treat or prevent further DDD are limited and surgery is required. Currently, surgical treatments resect structural damages, fuse the motion segments or perform 
total disc arthroplasty with the aim of removing the possible source of pain and restore biomechanical function. However, these procedures may promote degeneration of IVDs of neighbouring segments (Siepe et al., 2014). For this reason, treatments dedicated to restoring IVD homeostasis are greatly in demand, one of which is cell therapy. As Vedicherla and Buckley (2017) indicated, the ideal cell source for IVD regeneration should meet the following criteria: (i) being autologous, (ii) being easily accessible, (iii) providing sufficient cell yield, (iv) producing equivalent disc-like ECM in the absence of exogenous growth factor supplementation, (v) sustaining the harsh microenvironment of the IVD.

The present cell source gold standard for DDD therapy is autologous mesenchymal stromal cells (MSCs), isolated either from bone marrow or adipose tissue (Pennicooke et al., 2016). These cells have been favoured due to their accessibility and proliferative capacity. To date, the assumption for the lack of success of clinical trials in which MSCs have been employed for DDD treatment (Huang et al., 2013; Huang et al., 2014; Naqvi and Buckley, 2016) is that the injected MSCs do not adapt or even survive for a reasonable time in the exceptionally harsh environment of a progressively degenerating disc. The IVD environment is acidic (Urban, 2002) and has low concentrations of glucose and oxygen (Huang et al., 2014). Upon DDD, the environment becomes inflamed (Risbud and Shapiro, 2014), in addition to becoming more acidic (Ichimura et al., 1991). For this reason, other, more committed cell sources, such as articular chondrocytes (ACs) or NP cells, which are prone to survive harsher conditions, were also evaluated as possible cell sources for DDD therapy (Pennicooke et al., 2016). MSCs and ACs are two cell sources presently used in phase two clinical trials for the treatment of DDD (Pennicooke et al., 2016; Sakai and Andersson, 2015). It may be argued that chondrocytes produce a more hyaline or fibrolike cartilage rather than the gelatinous matrix of the healthy NP. Nonetheless, it is conceivable that increasing disc height through matrix production of administered cells may counterbalance the progression of disc degeneration even if the matrix is not completely analogous to that of a healthy NP. A comparative in vivo preclinical study between MSCs and committed ACs demonstrated that ACs are superior to MSCs with regard to cell survival and ECM production (Acosta et al., 2011). However, the harvesting of healthy autologous articular cartilage is difficult to consider, as an injury to a healthy joint would be required.

In recent years, nasal chondrocytes (NCs) have gained a reputation for cartilage tissue regeneration due to their robust cartilage-forming potential and adaptation capacity to the joint environment (Fulco et al., 2014; Mumme et al., 2016; Pelttari et al., 2014). In addition, previous work (Candrian et al., 2008; Scotti et al., 2012; Vedicherla and Buckley, 2017) has shown the superiority of NCs over ACs in cartilage regeneration, even under inflammatory and load-bearing conditions. These reports have promoted the concept of investigating NCs for the treatment of DDD by means of supporting the accumulation of NP-like matrix (Tsaryk et al., 2015; Tsaryk et al., 2017; Vedicherla and Buckley, 2017). One of the first steps for determining the potential of NCs as compared to other cell sources, which are at present most commonly used, is to test them in simulated IVD conditions before considering expensive and time-consuming preclinical models. Previously, in vitro experiments have been dedicated to analysing the behaviour of potential cell sources only within singular characteristics simulating the IVD environment. However, to determine the potential therapeutic value of NCs, it is necessary to analyse their behaviour in an in vitro setup mimicking various parameters of clinical conditions. With the goal of assessing whether NCs can be considered as a suitable cell source for cell therapy of DDD, the responses of NCs, in comparison to cell sources presently used in phase two clinical trials (i.e. MSCs and ACs) were investigated under in vitro hypoxic, low-glucose, acidic and inflamed conditions mimicking the physiological milieu of a degenerated IVD. In addition, a normoxic, high-glucose condition was included as a typical culture condition.

\section{Materials and Methods}

\section{Cell harvest}

Following informed consent and local ethical committee approval by the University Hospital Basel, Switzerland (reference number EK:78/07), human articular and nasal septal cartilage tissues were collected during autopsy from 3 individuals (2 male, 1 female, mean age 53 years, range 51-54 years), whereas bone marrow aspirates were obtained during routine orthopaedic procedures from the iliac crest of 3 donors ( 2 male, 1 female, mean age 24 years, range 17-30 years). NP tissue was acquired from 3 patients ( 2 male, 1 female, mean age 50 years, range 30-58 years) undergoing operations for lumbar spinal fusion [Pfirmann scale (Pfirrmann et al., 2001) of IVD of each patient was 2].

\section{Cell isolation and culture}

ACs and NCs were isolated by digestion with $0.15 \%$ type II collagenase for $22 \mathrm{~h}$ and resuspended in Dulbecco's modified Eagle's medium (DMEM; 10938-015, Gibco) containing $4.5 \mathrm{mg} / \mathrm{mL}$ D-glucose and $0.1 \mathrm{mM}$ non-essential amino acids and supplemented with $1 \mathrm{mM}$ sodium pyruvate (11360-039, Gibco), 100 mM 4-(2-hydroxyethyl)-1piperazineethanesulfonic acid (HEPES) buffer (15630056, Gibco), 100 units/mL penicillin, $100 \mu \mathrm{g} / \mathrm{mL}$ streptomycin and $0.29 \mathrm{mg} / \mathrm{mL}$ L-glutamine (10378016, Gibco) (basic medium). Chondrocytes were plated in tissue culture flasks at $1 \times 10^{4} \mathrm{cells} / \mathrm{cm}^{2}$ and cultured for two to three passages in basic medium 
supplemented with $10 \%$ foetal bovine serum (FBS) (10270-106, Gibco), $1 \mathrm{ng} / \mathrm{mL}$ transforming growth factor (TGF) $\beta 1$ (240-BO-10, R\&D) and $5 \mathrm{ng} / \mathrm{mL}$ fibroblast growth factor 2 (FGF2; 233-FB-025, R\&D), according to an established protocol (Barbero et al., 2003). MSCs were isolated and expanded in minimum essential medium alpha modification $(\alpha \mathrm{MEM})$-based basic medium supplemented with $5 \mathrm{ng} / \mathrm{mL}$ FGF2 for a total of two passages, according to an established protocol (Frank et al., 2002; Muller et al., 2009). NP cells were isolated by digestion with $0.05 \%$ type II collagenase for $22 \mathrm{~h}$ and resuspended in basic medium using DMEM: nutrient mixture F-12 (DMEM/F12; 21331-046, Gibco) supplemented with $5 \mathrm{ng} / \mathrm{mL}$ FGF2, according to the protocol described by Capossela et al. (2018). Medium was changed twice a week.

\section{Pellet culture model}

Pellet culture of primary chondrocytes or MSCs was performed in $0.5 \mathrm{~mL}$ of DMEM, $1 \mathrm{mM}$ sodium pyruvate, $100 \mathrm{mM}$ HEPES buffer, $1 \%$ insulintransferrin-selenium (51300-0449, Gibco), $0.56 \%$ linoleic acid (L9530, Sigma-Aldrich), $0.14 \%$ human serum albumin (43075, CSL Behring), $100 \mathrm{U} / \mathrm{mL}$ penicillin, $100 \mathrm{mg} / \mathrm{mL}$ streptomycin, $0.29 \mathrm{mg} / \mathrm{mL}$ L-glutamine, $0.1 \mathrm{mM}$ ascorbic acid 2-phosphate (A-8960, Sigma-Aldrich) and $10^{-7} \mathrm{M}$ dexamethasone (D-2915, Sigma-Aldrich) (chondrogenic medium). For standard conditions, DMEM containing either $1 \mathrm{mg} / \mathrm{mL}$ D-glucose (31885-023, Gibco) and $0.1 \mathrm{mM}$ non-essential amino acids (11140-050, Gibco) or $4.5 \mathrm{mg} / \mathrm{mL}$ D-glucose (10938-015, Gibco) was used. Acidic medium was prepared using $1 \mathrm{mg} / \mathrm{L}$ D-glucose DMEM powder (D5523, Gibco) dissolved in $\mathrm{ddH}_{2} \mathrm{O}$ and $\mathrm{pH}$ was adjusted to 7 by using sodium bicarbonate. The media were prepared $24 \mathrm{~h}$ prior to medium change and placed into their respective incubators to allow for adjustment to the $\mathrm{O}_{2}$ levels. $24 \mathrm{~h}$ incubation in hypoxia reduced the $\mathrm{pH}$ of standard media from 7.5 to 7.4 and acidic media from 7 to 6.8 . For the establishment of this protocol, both acidic and $\mathrm{O}_{2}$ levels were preliminarily assessed using the SDR SensorDish ${ }^{\circledR}$ Reader Basic Set (Precision Sensing $\mathrm{GmbH}$, Regensburg, Germany) in combination with the corresponding OxoDish ${ }^{\circledR}$ and HydroDish ${ }^{\circledR}$ plates.

250,000 cells were centrifuged in $1.5 \mathrm{~mL}$ conical polypropylene tubes (Sarstedt) to form spherical pellets (Muller et al., 2016). In case of chondrogenic priming, medium was supplemented with $10 \mathrm{ng} / \mathrm{mL}$ TGF 31 (240-BO-10, R\&D) for the first $7 \mathrm{~d}$. After a total of 4-week culture, pellets were processed as described below. For each experiment and experimental group, at least two replicate pellets per donor were assessed for each analysis. Medium was changed twice a week.

\section{Biochemical assays}

Generated tissues were digested for $16 \mathrm{~h}$ at $56{ }^{\circ} \mathrm{C}$ in proteinase K $[1 \mathrm{mg} / \mathrm{mL}$ proteinase K (P2308, SigmaAldrich) in $50 \mathrm{mM}$ Tris (A5456-3, Sigma-Aldrich) with $1 \mathrm{mM}$ ethylenediaminetetraacetic acid (EDTA; 03680,
Fluka), 1 mM iodoacetamide (I-1149, Sigma-Aldrich) and $10 \mathrm{mg} / \mathrm{mL}$ pepstatin A (P5318, Sigma-Aldrich)]. Glycosaminoglycan (GAG) content was determined spectrophotometrically using dimethyl methylene blue, with chondroitin sulphate as standard (Barbosa et al., 2003). DNA content was measured using the CyQuant cell proliferation assay kit (Invitrogen), with calf thymus DNA as standard.

Collagen assays were performed using Sirius Red Total Collagen Detection Assay Kit (9062, Chondrex), Human type I Collagen ELISA detection Kit (6021, Chondrex) and Multi-Species Type II Collagen ELISA Detection Kit (6018, Chondrex). All three assays were performed on the same samples. Samples were solubilised and processed according to the manufacturer's instructions.

\section{Quantitative real-time reverse transcriptase- polymerase chain reaction ( $q R T-P C R$ )}

Total RNA was extracted by combining the material of three replicate pellets. cDNA synthesis and qRTPCR (7300, Applied Biosystems) were performed as previously described (Barbero et al., 2003) to quantify expression levels of glyceraldehyde 3-phosphate dehydrogenase (GAPDH), Forkhead Box F1 (FoxF1), keratin 8 (KRT8), keratin 18 (KRT18), keratin 19 (KRT19), Paired Box 1 (PAX1), Sonic hedgehog (Shh), T Brachyury, T-box transcription factor T $(T)$, ovolike zinc finger $(\mathrm{OVO} 2)$, beta globin $(\mathrm{HBB})$, hypoxiainducible factor (HIF), TGF $\beta 1, T G F \beta 3$, interleukin 1 receptor 1 (IL1R1), IL6 receptor (IL6R), tumour necrosis factor alpha receptor $(T N F \alpha R)$, collagen types I, II and X by using human-specific primers and probes (Barbero et al., 2006) (Hs02758991, Hs01595539, Hs02827483, Hs00761767, Hs00230962, Hs00196352, HS01123832, Hs00610080, Hs02384746, Hs00758889, Hs00153153, Hs000998133, Hs01086000, Hs00991010, Hs01075664, Hs01042313, Hs00164004, Hs00264051, Hs00166657, respectively, Applied Biosystems). For each sample, $\mathrm{Ct}$ value of each target sequence was subtracted to $\mathrm{Ct}$ value of reference gene (human GAPDH, Hs02758991, Applied Biosystems) to derive the $\triangle \mathrm{Ct}$.

\section{Histology, immunohistochemistry and immunofluorescent histochemistry}

After culture, pellets were fixed in $4 \%$ paraformaldehyde, washed in PBS and embedded in Richard-Allan Scientific ${ }^{\mathrm{TM}}$ HistoGel $^{\mathrm{TM}}$ Specimen Processing Gel (HG-4000-012, ThermoFisher Scientific), a hydroxyethyl agarose which is combined with other chemical reagents. Richard-Allan Scientific ${ }^{\mathrm{TM}}$ HistoGel ${ }^{\mathrm{TM}}$ Specimen Processing Gel was heated until in its liquid state, then retained at $65^{\circ} \mathrm{C}$ using a water bath. Next, pellets were embedded in $30 \mu \mathrm{L}$ gel droplets. The use of this gel allows a simplified retrieval and embedding in the desired orientation after dehydration and paraffinisation, without affecting sample, staining procedure or attaining of histological images. $4 \mu \mathrm{m}$-thick sections were cut (Microm HM 430 or Microm HM 340E) and 
slides were dehydrated prior to staining. Safranin-O/ fast green (SafO/FG; SafO: 84120, Sigma-Aldrich; FG: F-7252, Sigma-Aldrich) stain with haematoxylin (J.T. Baker) nuclear counterstaining was performed to analyse chondrogenic tissue formation. For immunohistochemistry, sections were subjected to enzymatic epitope retrieval at $37^{\circ} \mathrm{C}$ first with $2 \mathrm{mg} /$ $\mathrm{mL}$ hyaluronidase (H3884, Sigma-Aldrich) and, then, with $1 \mathrm{mg} / \mathrm{mL}$ pronase (10165 921 001, Roche). After blocking the slides with $5 \%$ bovine serum albumin, the following primary antibodies were used: rabbit anti-type I collagen (Col1) human-specific, 1 : 1000 (ab138492, Abcam); mouse anti-type II collagen (Col2), human-specific, 1 : 1000 (63171, clone II4C11, MP Biomedicals). For immunofluorescence, immune-binding was detected with Alexa Fluor 488- or 564-conjugated secondary antibodies each at 1 : 500 (A21222 and A11030, Invitrogen, respectively) and DAPI was used as a nuclear counterstain. For immunohistochemistry, goat anti-mouse biotinylated secondary antibody $1: 200$
(E0433, Dako), VECTASTAIN ${ }^{\circledR}$ ABC_AP Staining KIT (AK-5000, Vector Laboratories) and VECTOR ${ }^{\circledR}$ Red Alkaline Phosphatase (Red AP) Substrate Kit (SK5100, Vector Laboratories) were used for detection; haematoxylin was used as a counterstain.

\section{Histology grading}

Two observers evaluated pellet culture sections stained with SafO/FG using a light microscope (Olympus IX-83) and graded them using the Bern scor system (Grogan et al., 2006). Both observers (2 basic scientists experienced in the examination of engineered cartilage) graded each sample blindly twice.

\section{Statistical analysis}

Two experimental replicates for each of the three donors (leading to a total of 6 experimental values) were used for the respective analysis. Each experimental replicate was based on the average of duplicate technical replicates. The results are

a
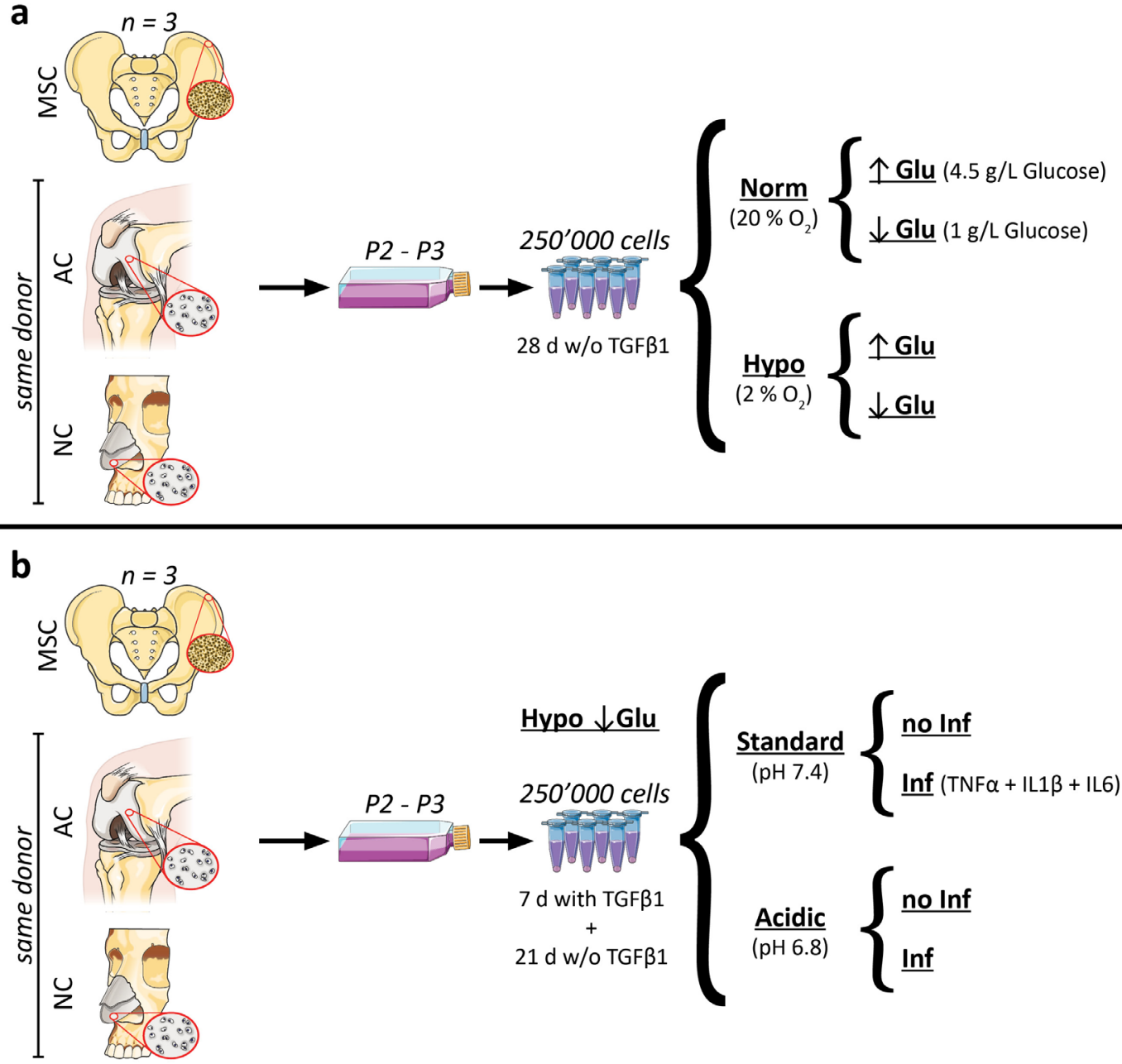

Fig. 1. Experimental design. MSCs from bone marrow aspirates and ACs and NCs from cartilage biopsies were each separately expanded and cultured as pellets for $28 \mathrm{~d}$. (a) Throughout the entire $28 \mathrm{~d}$ culture period, cells were cultured in high- $(\uparrow \mathrm{Glu}$ ) or low-glucose $(\downarrow \mathrm{Glu})$ medium devoid of TGF $\beta 1$ (w/o TGF $\beta 1)$ in $19 \% \mathrm{O}_{2}$ (normoxia, Norm) or $2 \% \mathrm{O}_{2}$ (hypoxia, Hypo). (b) Cells were cultivated in Hypo $\downarrow$ Glu conditions in standard ( $\mathrm{pH} 7.4$ ) or acidic ( $\mathrm{pH}$ 6.8) medium, as well as, in either presence (Inf) of the inflammation factors TNF $\alpha$, IL1 $\beta$ and IL6 or in their absence (no Inf). In the first $7 \mathrm{~d}$ of culture, cells were primed for chondrogenesis by supplementation of TGF $\beta 1$ to the respective media. 
presented as mean \pm standard deviation. Differences between experimental groups were assessed by two-way ANOVA with a Bonferroni's multiple comparison post-hoc test and considered statistically significant with $p<0.05$ (Prism 7, Graph Pad Software).

\section{Results}

\section{Cell responses to altered glucose and oxygen conditions}

In a first simplified experimental setup mimicking the physiological IVD environment, influence of hypoxia and low-glucose were evaluated. MSCs, ACs and NCs were exposed to normoxia $\left(20 \% \mathrm{O}_{2}\right)$ or hypoxia $\left(2 \% \mathrm{O}_{2}\right)$ in either high $(4.5 \mathrm{gr} / \mathrm{L})$ - or low (1 gr/L)-glucose chondrogenic medium for $28 \mathrm{~d}$ in micro-mass culture. The impact of these conditions was assessed by cell maintenance and proliferation, ECM production and expression of cartilage-specific genes (Fig. 1a). For this first investigation, cells were cultured in the absence of the strong chondrogenic factor TGF $\beta 1$.

Comparison of DNA content by means of a biochemical assay of cell-pellets at day 28 versus day 0 (d0) revealed that MSCs significantly maintained only $34 \%$ of their DNA contents in normoxic, highglucose conditions and between $65-75 \%$ in the other conditions. Interestingly, ACs had a more than 10$20 \%$ significant decrease in all conditions, whereas NCs displayed a trend to increase their DNA content by more than $10 \%$ in all conditions (Fig. 2). These results indicated a general superior tendency of NCs, as compared to the other cell sources, to survive/ proliferate.

Histological evaluation by SafO/FG stain revealed that there was no distinguishable GAG staining visible in MSCs in any condition (Fig. 3a, a.i-a.iv), with the exception of one donor in hypoxic, high-

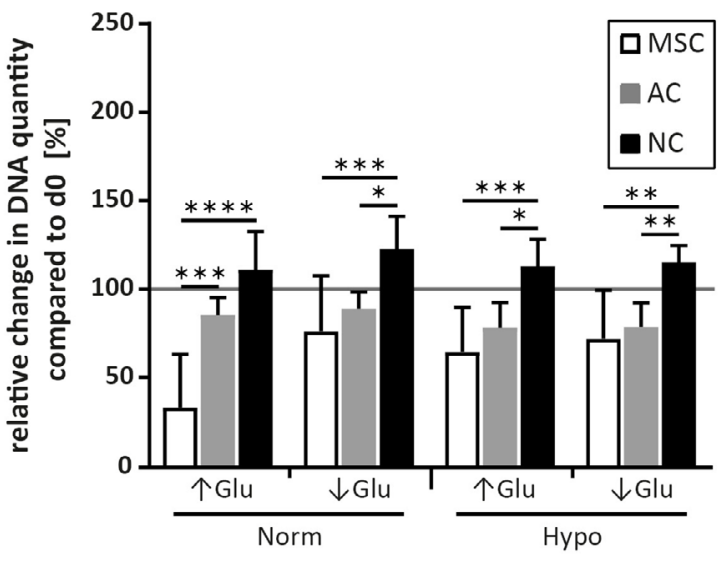

Fig. 2. Relative change in DNA content. Relative change in DNA content in MSCs, ACs and NCs after $28 \mathrm{~d}$ in high- ( $\uparrow \mathrm{Glu})$ or low-glucose $(\downarrow \mathrm{Glu})$ medium in normoxia (Norm) or hypoxia (Hypo) as compared to the corresponding cell type at day 0 (d0, post-expansion and pre-pellet culture). glucose conditions (Fig. 3a, a.iii top). Although ACs did not accumulate sufficient GAGs to be observable in both normoxic conditions (Fig. 3a, a.v-a.vi), faint red staining could be noticed in the two hypoxic conditions (Fig. 3a, a.vii-a.viii). However, NCs displayed a weak GAG staining in both normoxic conditions (Fig. 3a, a.ix-a.x), similar to the one found in ACs in either hypoxic conditions. Additionally, NCs showed a distinctive colouring for GAGs in hypoxic conditions (Fig. 3a, a.xi-a.xii).

SafO/FG-stained sections were further graded using the Bern score, which accounts for uniformity and intensity of matrix staining, cell density/extent of matrix produced and cellular morphologies (Grogan et al., 2006). The best scores for MSCs were found in the high-glucose conditions independent of the oxygen concentration. No statistically significant differences in total Bern score were observed between ACs and NCs. ACs and NCs significantly improved their overall score in hypoxic conditions, to the extent that in hypoxic, low-glucose conditions NCs significantly outranked MSCs. Additionally, in this condition, NC cell morphology was more rounded (Fig. 3b) than either MSCs or ACs (Table 1).

Biochemical findings confirmed evaluations made by SafO/FG histology. Only cells from one of the three MSC donors produced a tissue which contained a relevant amount of GAGs $(27.6 \pm 4.25 \mu \mathrm{g} /$ pellet) in hypoxic, high-glucose conditions. This well-known donor variability of MSCs led to the differences between hypoxic, high-glucose conditions and the two low-glucose conditions [normoxic, low-glucose (Norm $\downarrow$ Glu): $p=0.016$; hypoxic, lowglucose (Hypo $\downarrow$ Glu): $p=0.013$ ]. Furthermore, cells from all MSC donors cultured in either of the low-glucose conditions resulted in a negligible GAG accumulation ( $\leq 1 \mu \mathrm{g} /$ pellet). ACs showed limited GAG accumulation under all experimental conditions. Notably, NCs retained consistent GAG amounts in all conditions, with an exception in the hypoxic, high-glucose conditions, where NC pellets displayed a non-significant trend to accumulate more GAGs than in both normoxic conditions [normoxic, high-glucose (Norm $\uparrow$ Glu): $p=0.28$; Norm $\downarrow$ Glu, $p=0.21$ ] (Fig. 3c, c.i). Based on the biochemical results, the three cell sources behaved similarly in all conditions, except hypoxic, high-glucose conditions, where MSCs and NCs accumulated significantly more GAGs than ACs (MSCs, $p=0.024$; NCs, $p=0.028$ ). However, even though no further significant difference was determined, histology and biochemical GAG determination indicated a trend towards more GAGs contained in the NC pellets in both low-glucose conditions (Fig. 3a, a.x, a.xii, and c, c.i).

Normalisation of GAG to DNA displayed no significant differences between cells in any of the four conditions. Nonetheless, an increase in GAG per DNA could be observed in hypoxic, high-glucose conditions for MSCs and NCs. Furthermore, it should be noted that in both high-glucose conditions, 
a

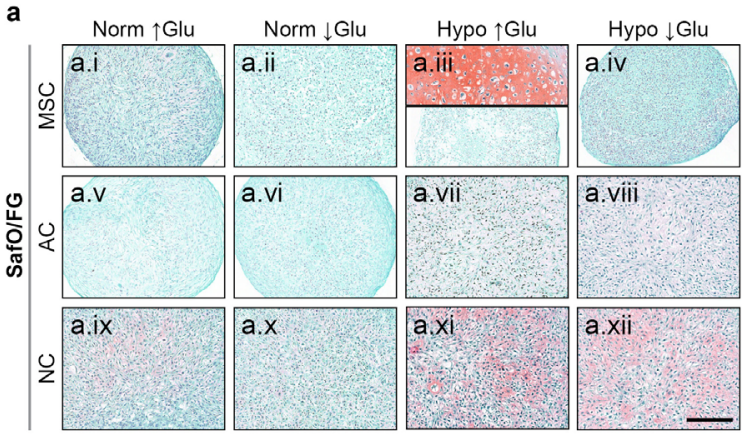

b

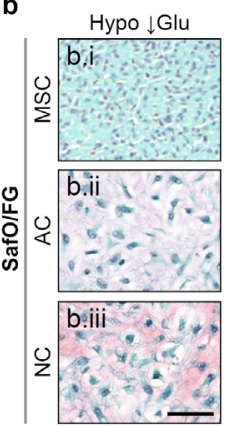

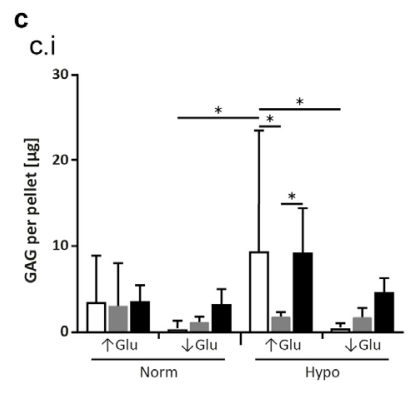
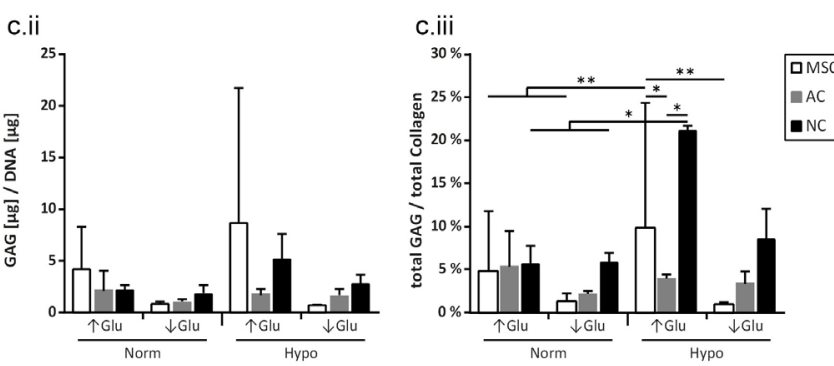

d

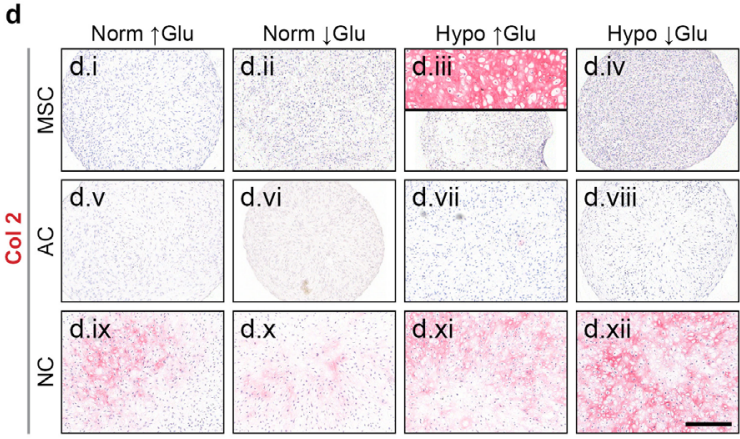

e e.i
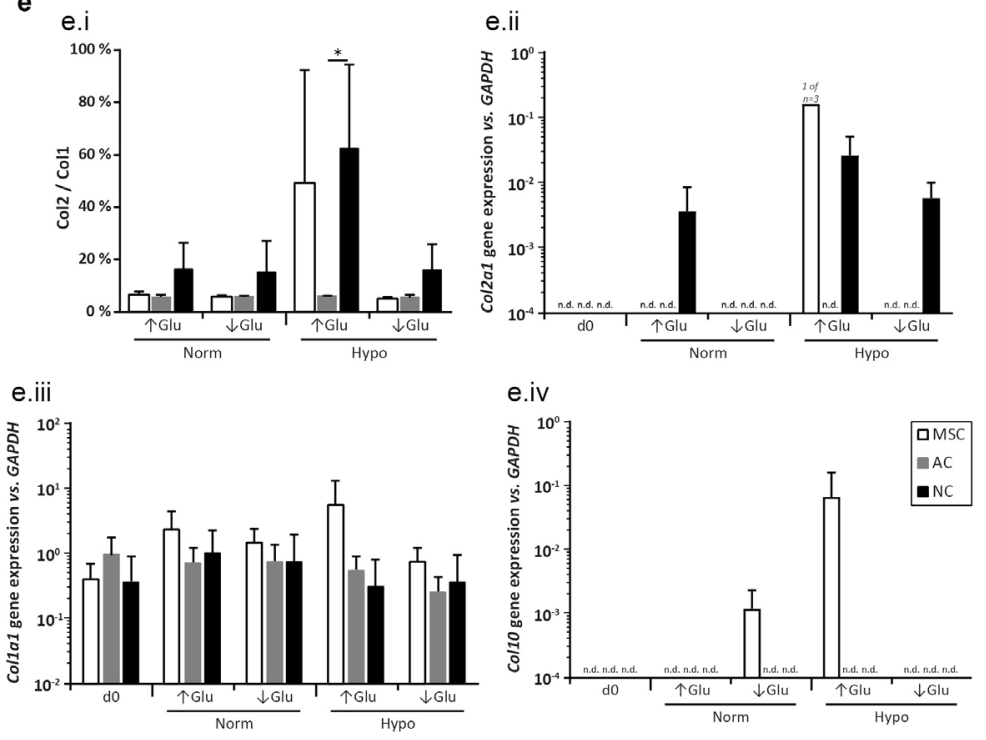

Fig. 3. ECM accumulation after pellet cultivation devoid of growth factor supplementation. (a) SafO/FG stain of representative pellets generated from i-iv) MSCs, v-viii) ACs, ix-xii) NCs after $28 \mathrm{~d}$ in high- ( $\uparrow$ Glu) or low-glucose ( $\downarrow$ Glu) medium in normoxia (Norm) or hypoxia (Hypo). Scale bar: $200 \mu m$. (b) Magnification of i) MSCs, ii) ACs, iii) NCs in Hypo $\downarrow$ Glu conditions. Scale bar: $5 \mu \mathrm{m}$. (c) Biochemical quantification of the average i) accumulated GAG of a pellet from the respective cell source; ii) accumulated GAG per DNA of the corresponding pellet; iii) accumulated GAG over accumulated total collagen per pellet. (d) Col2 immunohistochemical staining of sections adjacent to those stained for SafO/FG in the respective conditions. Scale bar: $200 \mu \mathrm{m}$. (e) i) ELISA measurements for Col2 over Col1 per pellet. ii-iv) Values of average qRT-PCR analysis carried out on pellets using human-specific primers for ii) Col2a1, iii) Col1a1, iv) Col10. Levels are expressed as fold of difference from GAPDH. Gene expression of Col2a1 in MSCs could only be detected in one of the three donors. ${ }^{*} p<0.05 ;{ }^{* *} p<0.01 ;$ n.d.: not detected. 
Table 1. Bern score of growth factor devoid pellets. Pellet culture of MSCs, ACs and NCs after $28 \mathrm{~d}$ in high- $(\uparrow \mathrm{Glu})$ or low-glucose ( $\downarrow \mathrm{Glu})$ medium in normoxia (Norm) or hypoxia (Hypo) were stained with $\mathrm{SafO} / \mathrm{FG}$ and evaluated using the Bern score system, which accounts for uniformity and intensity of matrix staining, cell density/extent of matrix produced and cellular morphology. All criteria have equal weight separately evaluated on a scale of 0 to 3 and are added together (Total) with a possible minimum collective score of 0 and a maximum of 9 . a $p<0.05$ between respective chondrocyte source and MSCs; ${ }^{\mathrm{b}} p<0.05$ between NCs and ACs.

\begin{tabular}{|l|c|c|c|c|c|c|}
\hline \multirow{2}{*}{} & \multicolumn{3}{|c|}{ Norm $\uparrow$ Glu } & \multicolumn{3}{c|}{ Norm $\downarrow$ Glu } \\
\cline { 2 - 7 } & MSCs & ACs & NCs & MSCs & ACs & NCs \\
\hline $\begin{array}{l}\text { Uniformity of } \\
\text { SafO/FG }\end{array}$ & 0.58 & 0.42 & 1.08 & 0.00 & 0.50 & $1.00^{\mathrm{a}}$ \\
\hline $\begin{array}{l}\text { Accumulated matrix } \\
\text { between cells }\end{array}$ & 1.42 & 0.67 & 0.67 & 0.25 & 0.58 & 1.00 \\
\hline Cell morphology & 1.17 & 0.92 & 1.75 & 0.08 & 0.67 & 1.00 \\
\hline Total & $3.17 \pm 2.57$ & $2.00 \pm 0.50$ & $3.50 \pm 0.90$ & $0.33 \pm 0.29$ & $1.75 \pm 0.66$ & $3.00 \pm 1.75$ \\
\hline & MSCs & ACs & NCs & MSCs & ACs & NCs \\
\cline { 2 - 8 } & 0.83 & 0.75 & 2.00 & 0.00 & 1.00 & 1.08 \\
\hline $\begin{array}{l}\text { Uniformity of } \\
\text { SafO/FG }\end{array}$ & 1.08 & 1.00 & 1.75 & 0.08 & 0.92 & 1.33 \\
\hline $\begin{array}{l}\text { Accumulated matrix } \\
\text { between cells }\end{array}$ & 0.92 & 1.17 & 2.00 & 0.00 & 0.83 & $1.83^{\mathrm{a}}$ \\
\hline Cell morphology & $2.83 \pm 4.69$ & $2.92 \pm 0.76$ & $5.75 \pm 0.35$ & $0.08 \pm 0.14$ & $2.75 \pm 2.00$ & $4.25^{\mathrm{a}} \pm 2.61$ \\
\hline Total & & & & & Hypo $\uparrow \mathrm{Glu}$ & \\
\hline
\end{tabular}

MSCs displayed a higher GAG per cell ratio than either chondrocyte type. Additionally, NCs tended to accumulate slightly more GAGs per cell in lowglucose conditions than MSCs and ACs (Fig. 3c, c.ii).

A feature of the NP is its high GAG to collagen ratio. The GAG to collagen ratio showed that MSCs and NCs in hypoxic, high-glucose conditions had a significantly higher ratio than ACs in the same condition, as well as their respective counterparts in both normoxic conditions. GAG to collagen ratio for MSCs in hypoxic, high-glucose condition was also significantly higher than in hypoxic, low-glucose conditions. The same comparison for NCs showed a non-significant decrease. Although no differences could be determined between the three cell types in normoxic, high-glucose conditions, NCs trended towards a higher GAG to collagen ratio than the other cell sources in the other three conditions (Fig. 3c, c.iii).

Immunohistochemistry for Col2 showed no detectable staining in either AC or MSC pellets in any of the conditions (Fig. 3d, d.i-d.viii), except for the same single MSC donor in hypoxic, low-glucose conditions, which also accumulated a considerable amount of GAGs (Fig. 3d d.iii top). Notably, Col2 accumulated in NCs in all conditions (Fig. 3d, d.ix-d.xii). However, in normoxic, low-glucose conditions, staining was rather weak. The comparison of accumulated Col2 versus accumulated Col1, as measured by enzyme-linked immunosorbent assay (ELISA), displayed that in hypoxic, high-glucose conditions, MSCs and NCs had the highest Col2/Col1 ratio in comparison to the other conditions. Moreover, clear trends towards higher Col2/Col1 ratio between NCs and MSCs or ACs were observed in all other conditions (Fig. 3e, e.i).

Analysis of gene expression of COL2a1 was in accordance with immunohistochemistry. COL2a1 levels were not detectable for ACs in any of the four conditions. Gene expression of COL2a1 was detectable in NCs in all conditions except for lowglucose medium in normoxia (Fig. 3e, e.ii), in which Col2 staining was also the weakest.

COL1a1 expression levels remained consistent for all cell types from post-expansion $\mathrm{d} 0$ to differentiation at day 28, respectively, except hypoxic, low-glucose MSCs. These portrayed heightened levels due to the previously described chondrogenic outlier (Fig. 3e, e.iii). Furthermore, mRNA for COL10a1 was only detected in MSCs under normoxic, low-glucose and hypoxic, high-glucose conditions (Fig. 3e, e.iv).

In summary, the data reveal that in the absence of the chondrogenic growth factor TGF $\beta 1$, despite originating from different donors, only NCs were capable of producing consistently crucial ECM 
components of cartilaginous tissue in hypoxic, lowglucose conditions resembling those in the IVD to a higher degree than ACs or MSCs. However, the extent of chondrogenesis was generally weak in the absence of TGF $\beta 1$ supplementation; therefore, it could be speculated that the presence of such a growth factor induces cells to produce ECM that could protect them from the harsh environment of the degenerated IVD and, thus, probably improve ECM deposition in a therapeutic clinical approach.

The influence of chondrogenic priming in an in vitro model of a degenerated disc environment

The complexity of the in vitro model was increased to more closely mimic the physiological environment of a degenerated disc, together with the application of the chondrogenic growth factor TGF $\beta 1$. The degenerated disc is not only a hypoxic, low-glucose environment but is also acidic and inflamed. The mildly degenerated disc environment is considered to have a pH of 6.8 (Gilbert et al., 2016; Naqvi and Buckley, 2016) and proinflammatory cytokines, such as TNF $\alpha$, IL1 $\beta$ and IL6, are believed to be key mediators of disc degeneration by driving the catabolic cascades associated with the disease
(Johnson et al., 2015; Molinos et al., 2015; Risbud and Shapiro, 2014). To implement these conditions in vitro, in addition to the hypoxic, low-glucose conditions for $28 \mathrm{~d}$, medium was adjusted to have a $\mathrm{pH}$ of 6.8 and/or the proinflammatory cytokines TNF $\alpha$, IL1 $\beta$ and IL6 (100 pg/mL each) were supplemented to the medium. The concentrations were selected in the range of magnitude as found in patient pathological conditions (Akyol et al., 2010; Altun, 2016). Considering that, in a therapeutic setup, growth factors would be injected into the disc only once with the cells and that these factors dissipate over time, TGF $\beta 1$ was only added for the first $7 \mathrm{~d}$, which could be considered chondrogenic instructional priming (Fig. 1b). In a preliminary assessment, primed cells in normoxic, high-glucose conditions were compared to cells continuously exposed to TGF $\beta 1$ throughout culture in the respective conditions to determine whether the $7 \mathrm{~d}$ priming would be sufficient to evoke the cell chondrogenic potential. SafO/FG stain and GAG quantification data indicated that $7 \mathrm{~d}$ TGF $\beta 1$ preculture was sufficient to promote ECM deposition by all cell types even if to a lower extent than 28 d. (Fig. 4). However, $7 \mathrm{~d}$ of TGF $\beta 1$ priming were better than no TGF $\beta 1$ supplementation (Fig. a
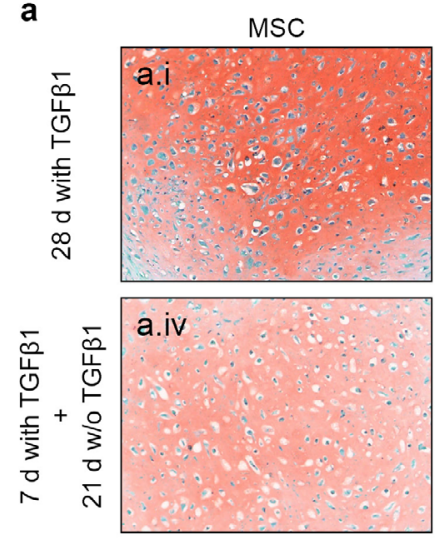

$\bar{b}$

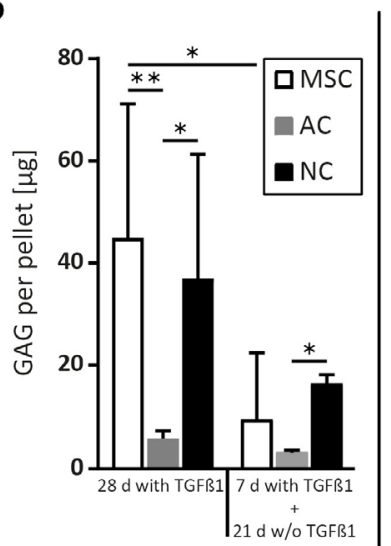

C.i

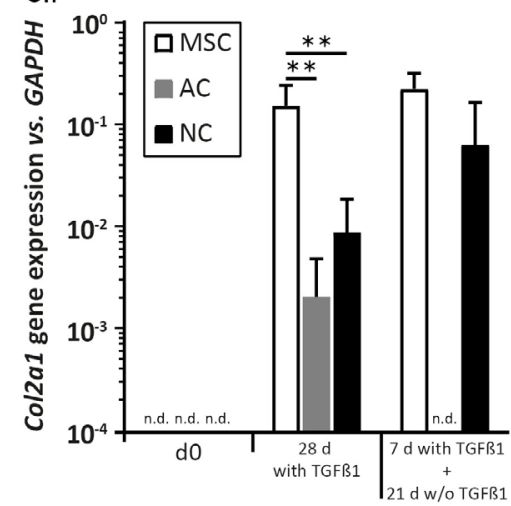

$A C$
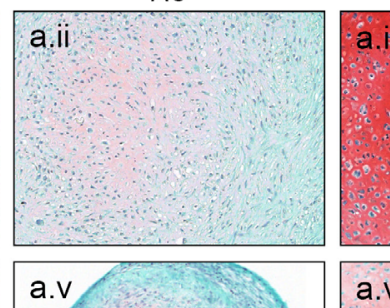

NC

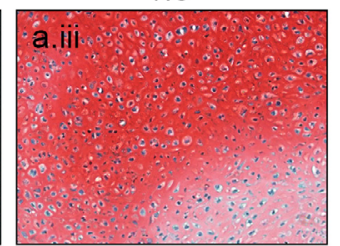

a.vi

Fig. 4. Continuous TGF $\beta 1$ supplementation vs. $7 \mathrm{~d}$ of chondrogenic priming. (a) SafO/FG stain of representative pellets generated from $\mathrm{i}$ and iv) MSCs, ii and v) ACs, iii and vi) NCs after $28 \mathrm{~d}$ in high-glucose ( $\uparrow \mathrm{Glu}$ ) medium in normoxia (Norm) with either i-iii) continuous supplementation of TGF $\beta 1$ (+ $28 \mathrm{~d}$ with TGF $\beta 1$ ) or iv-vi) $7 \mathrm{~d}$ supplementation of TGF $\beta 1$ and $21 \mathrm{~d}$ without $(7 \mathrm{~d}$ with TGF $\beta 1+21 \mathrm{~d}$ w/o TGF $\beta 1)$. Scale bar: $200 \mu \mathrm{m}$. (b) Biochemical quantification of average accumulated GAGs; cell sources and conditions are indicated. (c) Values of average qRT-PCR analysis carried out on pellets and cells post-expansion at day 0 (d0) of pellet culture using human-specific primers for i) Col2a1 and ii) Col1a1. Levels are expressed as fold of difference from GAPDH. ${ }^{*} p<0.05 ;{ }^{* *} p<0.01 ;{ }^{* *} p>0.001$; n.d.: not detected. 
4 vs. Fig. 3). For this reason, TGF $\beta 1$ priming was included in the pellet culture of cells exposed to the degenerated IVD conditions (Fig 1b). To have a reference to the previous experimental setup, effects of priming were also analysed in hypoxic, low-glucose conditions without acidic medium or supplemented inflammation factors.

Interestingly, priming in hypoxic, low-glucose conditions only induced production of cartilage matrix in the one MSC donor, who was also chondrogenic in hypoxic, high-glucose conditions without TGF $\beta 1$ (Fig. 5a, a.i, a.v top). Nonetheless, the chondrogenic capacity of this donor was drastically reduced in the presence of proinflammatory cytokines (Fig. 5a, a.ii and a.vi). In both acidic conditions, MSCs did not condense to form a pellet and, thus, were not retrievable after 4 weeks (Fig. 5a, a.iii, iv, vii, viii).

Although a limited amount of GAG could be observed from ACs in all non-acidic conditions
(Fig. 5b, b.i-b.ii), Col2 could not be distinguished by fluorescent immunohistochemistry in any of the four conditions (Fig. 5b, b.v-b.viii). Acidic conditions did not inhibit ACs from aggregating into pellets. However, GAG staining was not visible by SafO/ FG colouring (Fig. 5b, b.iii, b.iv). In contrast, NCs produced both GAGs and Col2 in all non-acidic conditions (Fig. 5c, c.i-c.ii, c.v-c.vi). Moreover, NCs performed significantly better than MSCs in Bern score evaluation in the same conditions especially in the category "Cell Morphology", where NCs significantly outranked MSCs in hypoxic, lowglucose, standard, inflamed conditions (Table 3). High magnification images show that well-formed lacunae were present in NC-engineered cartilage as compared to ACs (Fig. 5d). As with ACs, NCs also aggregated into pellets in both acidic environments with no GAGs or Col2 observable by histology (Fig. 7c, c.iii, iv, vi, viii). Furthermore, no distinguishable
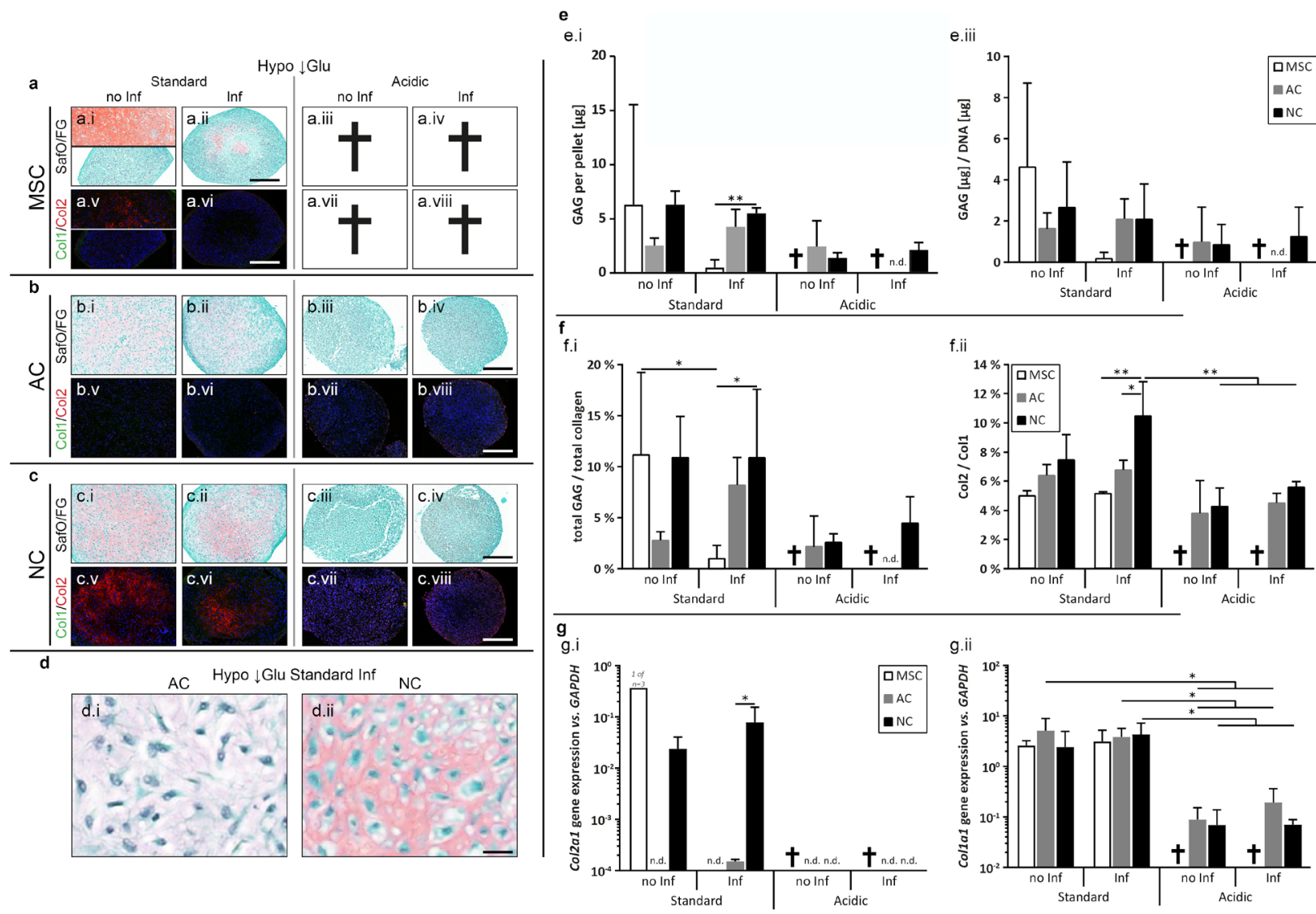

Fig. 5. ECM accumulation after chondrogenesis primed pellet cultivation. Histological sections of (a) MSCs, (b) ACs and (c) NCs stained for i-iv) SafO/FG and vi-viii) fluorescent immunohistochemically for Col1 (green) and Col2 (red) after $28 \mathrm{~d}$ in hypoxic, low-glucose conditions (Hypo $\downarrow$ Glu) and TGF $\beta 1$ supplementation for the first $7 \mathrm{~d}(+7 \mathrm{~d}$ TGF 31$)$ in standard $(\mathrm{pH} 7.4)$ or acidic ( $\mathrm{pH}$ 6.8) medium supplemented with the inflammation factors TNF $\alpha$, IL1 $\beta$, IL6 (Inf) or devoid of these (no Inf). Scale bar: $200 \mu$ m. (d) Magnification of SafO/FG stain for i) ACs and ii) NCs in of Hypo $\downarrow$ Glu, standard, infection conditions. Scale bar: $5 \mu \mathrm{m}$. (e) Biochemical quantification of i) average accumulated GAGs and iii) average accumulated GAGs per DNA; cell source and condition are indicated. (f) i) Biochemical analysis of average total accumulated GAGs per total accumulated collagen per respective pellet; ii) average Col2 over Col1 per pellet measured by ELISA. (g) Values of average qRT-PCR analysis carried out on pellets using human-specific primers for i) Col2a1 and ii) Col1a1. Level per pellets are expressed as fold of difference from GAPDH. ${ }^{*} p<0.05$; ${ }^{* *} p<0.01$; n.d.: not detected; $†$ : cells not retrieved. 
Table 2. Average accumulated GAGs in ACs and NCs donors in acidic conditions. n.d.: not detected.

\begin{tabular}{|c|c|c|c|c|c|c|}
\hline \multirow{2}{*}{ GAG $(\mu \mathrm{g})$} & \multicolumn{2}{|c|}{ Donor 1 } & \multicolumn{2}{c|}{ Donor 2 } & \multicolumn{2}{c|}{ Donor 3 } \\
\cline { 2 - 7 } & AC & NC & AC & NC & AC & NC \\
\hline \multirow{2}{*}{ Acidic No Inf } & n.d. & $1.00 \pm 0.02$ & n.d. & $1.87 \pm 0.10$ & $\begin{array}{c}4.76 \pm \\
0.23\end{array}$ & $1.13 \pm 0.01$ \\
\hline Acidic Inf & n.d. & $1.40 \pm 0.03$ & n.d. & $2.78 \pm 0.19$ & n.d. & $2.00 \pm 0.03$ \\
\hline
\end{tabular}

Table 3. Bern score of chondrogenesis primed pellets. Pellet culture of MSCs, ACs and NCs after $28 \mathrm{~d}$ in hypoxic, low glucose conditions (Hypo $\downarrow$ Glu) and TGF $\beta 1$ supplementation for the first $7 \mathrm{~d}(+7 \mathrm{~d}$ TGF $\beta 1$ ) in standard ( $\mathrm{pH} 7.4$ ) or acidic ( $\mathrm{pH}$ 6.8) medium supplemented with the inflammation factors TNF $\alpha$, IL1 $\beta$, IL6 (Inf) or devoid of these (no Inf) were stained with SafO/FG and evaluated using the Bern score system. ${ }^{\text {a }} p<0.05$ between respective chondrocyte source and MSCs; ${ }^{b} p<0.05$ between NCs and ACs; + : cells not retrieved.

\begin{tabular}{|c|c|c|c|c|c|c|}
\hline & \multicolumn{3}{|c|}{ Standard no Inf } & \multicolumn{3}{|c|}{ Standard Inf } \\
\hline & MSCs & ACs & NCs & MSCs & ACs & NCs \\
\hline $\begin{array}{l}\text { Uniformity of } \\
\text { SafO/FG }\end{array}$ & 1.00 & 1.00 & 1.75 & 0.50 & 1.67 & 1.83 \\
\hline $\begin{array}{l}\text { Accumulated matrix } \\
\text { between cells }\end{array}$ & 1.17 & 1.25 & 1.83 & 0.75 & 1.92 & 1.83 \\
\hline Cell morphology & 1.08 & 1.17 & 2.17 & 0.83 & 1.58 & $2.17^{\mathrm{a}}$ \\
\hline \multirow[t]{3}{*}{ Total } & $3.25 \pm 4.55$ & $3.42 \pm 1.44$ & $5.75^{\mathrm{b}} \pm 0.75$ & $2.08 \pm 1.38$ & $5.17^{a} \pm 0.76$ & $5.83^{a} \pm 2.02$ \\
\hline & \multicolumn{3}{|c|}{ Acidic no Inf } & \multicolumn{3}{|c|}{ Acidic Inf } \\
\hline & MSCs & ACs & NCs & MSCs & ACs & NCs \\
\hline $\begin{array}{l}\text { Uniformity of } \\
\text { SafO/FG }\end{array}$ & $\dagger$ & 0.25 & 0.08 & $\dagger$ & 0.08 & 0.17 \\
\hline $\begin{array}{l}\text { Accumulated matrix } \\
\text { between cells }\end{array}$ & $t$ & 0.50 & 0.17 & $t$ & 0.58 & 0.33 \\
\hline Cell morphology & 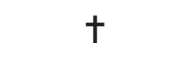 & 0.50 & 0.25 & $t$ & 0.50 & 0.75 \\
\hline Total & + & $1.25 \pm 0.00$ & $0.5 \pm 0.5$ & + & $1.17 \pm 0.14$ & $1.25 \pm 0.66$ \\
\hline
\end{tabular}

difference could be observed between ACs and NCs in the respective Bern scoring of the individual acidic conditions (Table 3).

Biochemistry for GAG content supported the findings of the histological analysis. Primed NCs and MSCs accumulated similar amounts of GAGs in normoxic, high-glucose conditions (Fig. 4b) and in hypoxic, low-glucose conditions (Fig. 5e-e.i). ACs accumulated less than either MSCs or NCs. Nonetheless, in hypoxic, low-glucose, inflamed conditions, ACs accumulated amounts of GAG comparable to NCs, whereas MSCs accumulated virtually none, being significantly different from both chondrocyte types (Fig. 5e, e.i). In hypoxic, lowglucose, acidic conditions, GAG accumulation could only be detected in one AC donor (Table 2). None of the NCs accumulated the same amount of GAGs as this one donor; however, GAG accumulation could be measured for each donor (Table 2). When proinflammatory factors were added to this acidic environment, no GAGs could be detected from any
AC pellet. Notably, however, NCs retained the same accumulation of GAGs as without inflammation factors in the respective conditions (Fig. 5e, e.i, Table 2).

GAG to DNA ratio showed no significant differences between all three cell types in either standard condition. However, a clear trend towards higher GAG per cell performance could be observed between either chondrocyte types and MSCs in hypoxic, low-glucose, inflamed conditions. Moreover, in acidic, non-inflamed conditions, both ACs and NCs had comparable GAG per cell performance, which NCs retained even in acidic, inflamed conditions (Table 2i). Corresponding results for GAG to DNA ratio could also be observed for total accumulated GAG to total accumulated collagen ratio in the respective conditions. MSCs significantly reduced GAG to collagen ratio in standard, inflamed conditions as compared to standard, non-inflamed conditions. ACs retained a constant GAG to collagen ratio in both standard and 
acidic, non-inflamed conditions. Interestingly, ACs displayed a non-significant increase in their GAG to collagen proportion when cultured in the presence of inflammation factors in standard conditions. On the other hand, NCs displayed no changes in GAG to collagen ratio between inflamed and noninflamed standard conditions. However, the ratio was similarly reduced for both conditions when NCs were additionally cultured in an acidic environment (Fig. 5f, f.i).

The comparison between the accumulated Col2 versus Col1 was similar in the three cell types in standard, non-inflamed conditions. Interestingly, in the presence of inflammation factors in standard conditions, MSCs and ACs retained a similar Col2 to Col1 ratio, whereas NCs had a trend towards an increased ratio. This increase led to a significant difference between NCs and the other two cell sources in the standard, inflamed conditions. However, this spike in performance was significantly altered when NCs were within an acidic environment, where they fell back to a similar Col2 to Col1 ratio to ACs (Fig. 5f, f.ii).

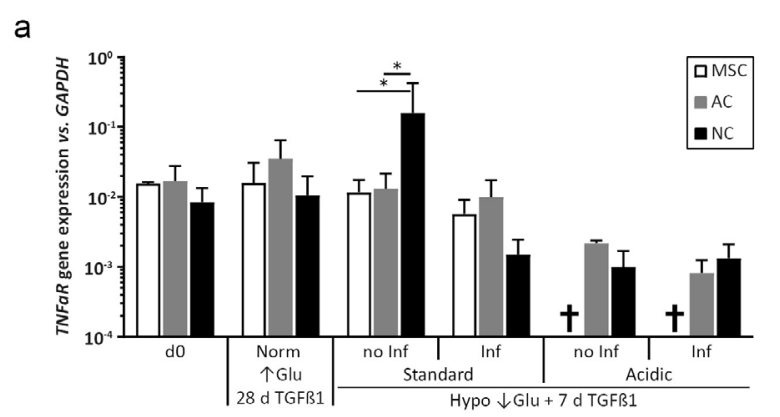

qRT-PCR for COL2a1 was consistent with the immunohistochemistry, only the one MSC donor, who was chondrogenic in hypoxic, high-glucose conditions, expressed Col2a1 in the standard, noninflamed conditions. Gene expression of Col2a1 could not be detected in ACs in standard, non-inflamed conditions. However, low detection was present in standard, inflamed conditions. Nonetheless, this was significantly lower than the Col2a1 gene expression of NCs in standard, inflamed conditions (Fig. 5g, g.i). Gene expression for COL1a1 displayed no difference between the different cell sources in either standard condition. Although COL1a1 gene expression was significantly reduced for both chondrocytes from standard to acidic conditions, no differences were identified between ACs and NCs in the respective acidic conditions (Fig. 5g, g.ii).

Even though MSCs could be primed for chondrogenesis, harsh environmental conditions and donor variability played a crucial role in their successful chondrogenesis and survival. ACs were sensitive to priming in that they could accumulate GAGs. Even though ACs had comparable Col2 vs.

b
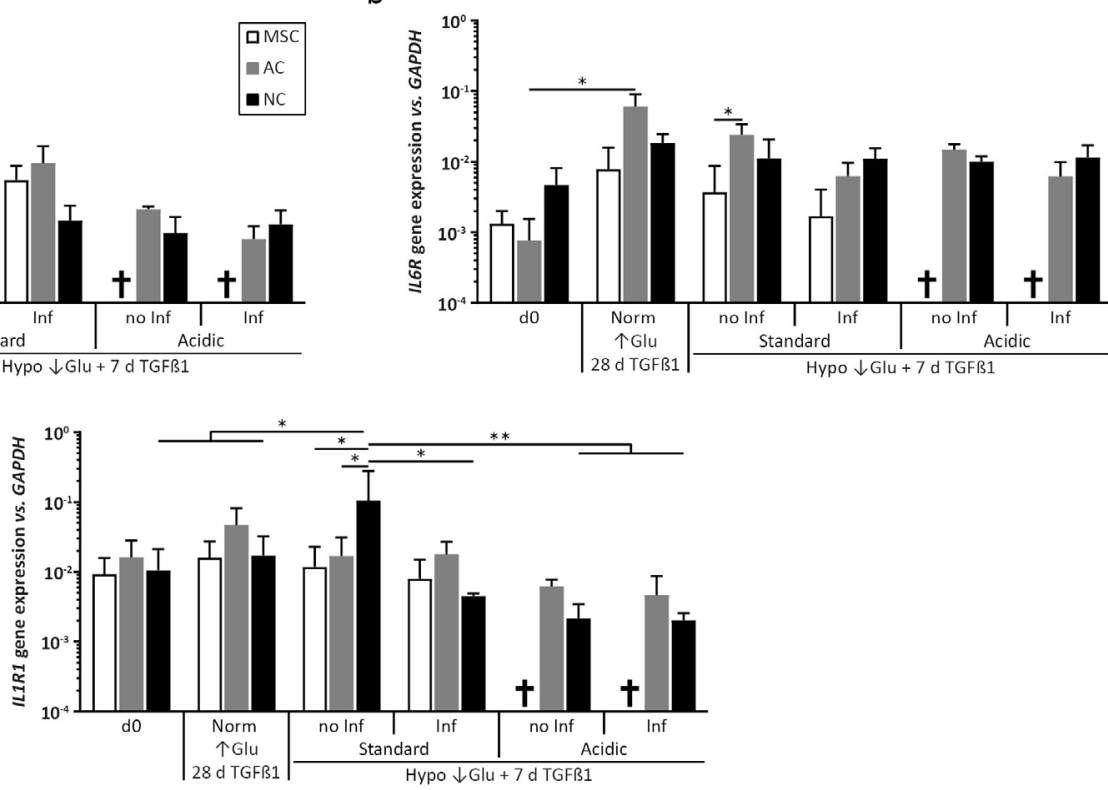

d

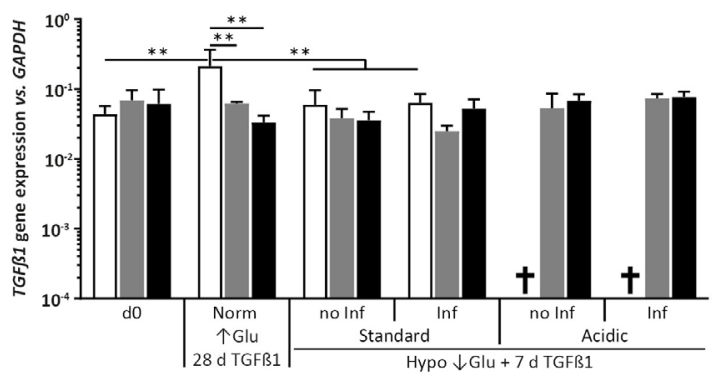

e

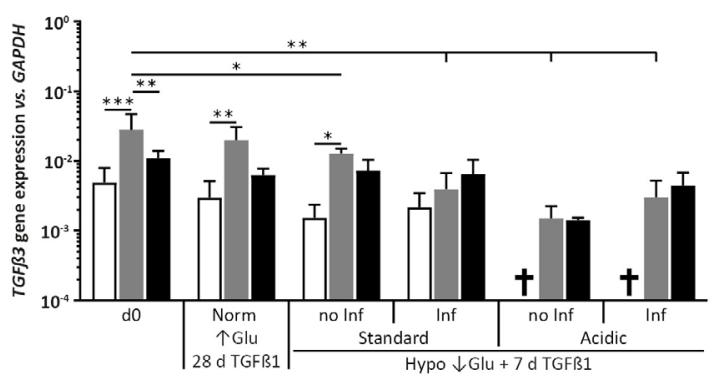

Fig. 6. Gene profile of cytokine receptors and TGF $\beta 1$ and TGF $\beta 3$ in response to in vitro degenerated IVD model.Values of average qRT-PCR analysis carried out using human-specific primers for (a) TNF $\alpha$ receptor (TNFaR), (b) IL6R, (c) IL1R1, (d) TGF 1 and (e) TGF 33. Pellets were cultured for $28 \mathrm{~d}$ in high-glucose ( $\uparrow G l u)$ in normoxia (Norm) condition or in low-glucose ( $\downarrow$ Glu) and hypoxia (Hypo) conditions combined with either standard ( $\mathrm{pH} 7.4$ ) or acidic ( $\mathrm{pH}$ 6.8) medium, with (Inf) or without (no Inf) the proinflammatory factors TNF $\alpha$, IL1 $\beta$ and IL 6 and with the supplementation of TGF $\beta 1$ for the first $7 \mathrm{~d}(+7 \mathrm{~d}$ TGF $\beta 1)$. $\mathrm{d} 0$ : day 0 of pellet culture. Levels are expressed as fold of difference from GAPDH. ${ }^{*} p<0.05$; ${ }^{* *} p<0.01$; ${ }^{* * *} p<0.001$; n.d.: not detected. 
Col1 ratio to NCs, they lacked the ability to express detectable amounts of COL2a1. Furthermore, in standard conditions, the addition of inflammation factors increased AC GAG to collagen ratio. Indeed, primed NCs produced ECM containing both GAG and Col2 in all non-acidic conditions. Even though an acidic environment reduced GAG accumulation in NCs, reproducible detection throughout donors was witnessed for both acidic conditions as opposed to ACs. GAG to collagen ratio in NCs was reduced in acidic conditions. However, they retained a steady state in both inflamed and non-inflamed acidic media. In addition, Col2 to Col1 accumulation was at its highest in standard, inflamed conditions and in a reduced steady state in both acidic conditions, similar to that of ACs. This indicated that, upon chondrogenic priming, NCs were considerably more resilient to a harsh IVD environment than MSCs and comparable, if not slightly more adept, to ACs.

\section{Expression of inflammation-related factors}

To address why ACs and NCs were less affected than MSCs by proinflammatory cytokines in nonacidic conditions, the expression of the receptors for the corresponding factors were investigated. Surprisingly, mRNA expression of TNF $\alpha R, I L 6 R$ and IL1R1 was not significantly different for cell sources in same conditions, except for in hypoxic, low-glucose, standard, non-inflamed conditions (Fig. $6 \mathbf{a}, \mathbf{b}, \mathbf{c}$ ). In these circumstances, NCs displayed a significantly higher level of ILIR1 and TNF $\alpha R$ gene expression in comparison to ACs and MSCs. However, these increases in mRNA expression, when compared to cells at d0, were not observed in either inflamed or acidic conditions or in a combination of both (Fig. $6 \mathbf{a}, \mathbf{b}, \mathbf{c})$. Interestingly, gene expression of $T N F \alpha R$ and IL1R1 in NCs was down-regulated in acidic, inflamed conditions as compared to standard, noninflamed conditions. However, gene expression of the two receptors was increased as compared to cells post-expansion at $\mathrm{d} 0$ and primed cells cultured in normoxic, high-glucose conditions. A further variance could be observed in ACs in standard, non-inflamed conditions, where cells displayed a statistically significant higher expression of IL6R as compared to MSCs. Moreover, IL6R expression increased upon post-expansion culture in all conditions as compared to $\mathrm{d} 0$. However, such an increase was statistically significant only in normoxic, high-glucose conditions.

Gene expression of the multifunctional cytokines TGF $\beta 1$ and TGF $\beta 3$, which promote chondrogenesis, was quantified. ACs and NCs retained a constant TGF $\beta 1$ expression in all culture conditions after $28 \mathrm{~d}$ as after expansion, whereas MSCs had increased TGF $\beta 1$ expression levels when primed and cultured in normoxic, high-glucose conditions. However, when MSCs were cultured in hypoxia with low glucose, they displayed the same level of expression as at $\mathrm{d} 0$

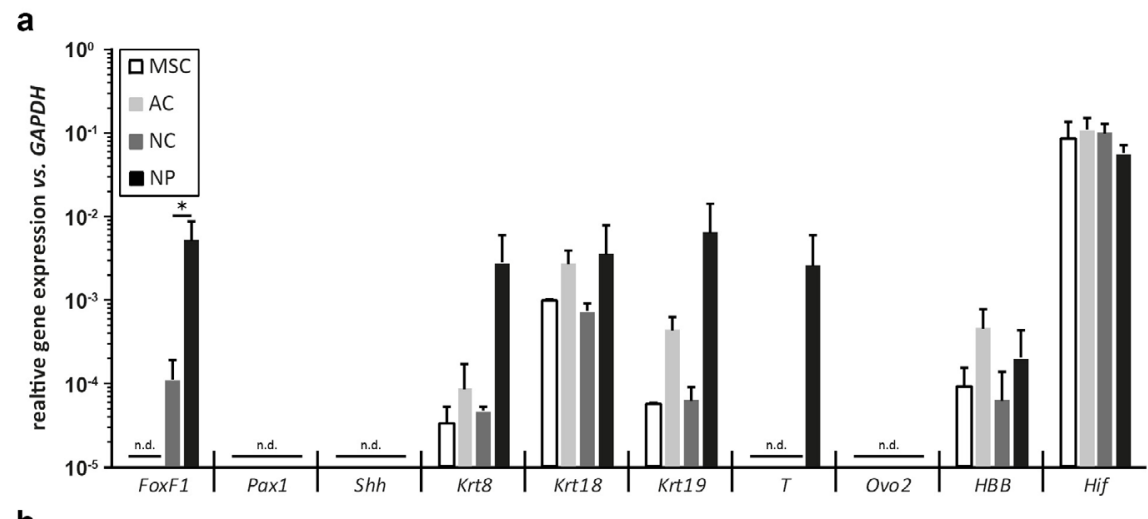

b

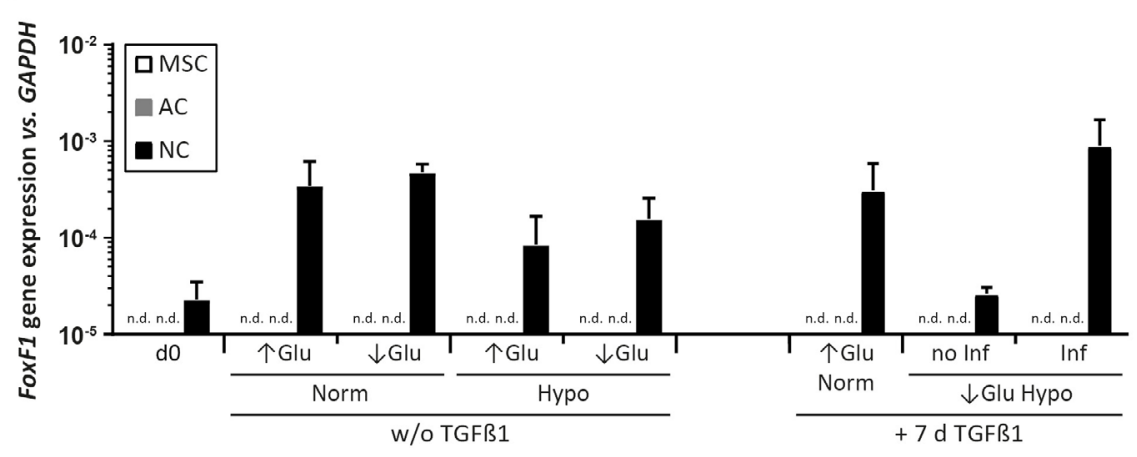

Fig. 7. Comparison of NP markers versus MSCs, ACs and NCs. (a) Gene expression of NP markers FoxF1, Pax1, Shh, Krt8, Krt18, Krt19, T, Ovo2, HBB and HIF in MSCs, ACs, NCs and NP cells cultured in hypoxic, low-glucose conditions with TGF31 supplementation. (b) Gene expression of FoxF1 in MSCs, ACs and NCs in high- $(\uparrow \mathrm{Glu})$ or low-glucose $(\downarrow \mathrm{Glu})$ medium in normoxia (Norm) or hypoxia (Hypo) devoid of TGF $\beta 1$ (w/o TGF $\beta 1$ ) or chondrogenically primed with TGF $\beta 1$ (+ $7 \mathrm{~d}$ TGF $\beta 1$ ) and with (Inf) or without (no Inf) the proinflammatory factors TNF $\alpha$, IL1 $\beta$ and IL6. Values of average qRT-PCR analysis carried out using humanspecific primers for respective genes. Levels are expressed as fold of difference from GAPDH. n.d.: not detected. 
(Fig. 6d). TGF 33 gene expression was significantly higher in ACs than in MSCs and NCs prior to culture at $\mathrm{d} 0$. ACs retained a stronger gene expression than MSCs in primed normoxic, high-glucose, as well as in hypoxic, low-glucose, standard, noninflamed conditions. Nonetheless, ACs had reduced expression of TGF $\beta 3$ mRNA in an inflamed or acidic environment. Primed NCs had a similar TGF $\beta 3$ expression in all displayed conditions as compared to $\mathrm{d} 0$ cells. In any of the primed hypoxic, low-glucose conditions, gene expression in NCs was comparable to that in ACs (Fig. 6e).

\section{Screening for varied expression of NP markers in the different cell sources}

Many studies have compared gene expression in ACs to NP cells to distinguish and identify NP specific genotypic markers, which could contribute to physiologic consequences and dictate NP cell function (Lv et al., 2014; Risbud et al., 2015; RodriguesPinto et al., 2013). Based on these studies, the markers Krt8, Krt18, Krt19, T, FoxF1, Pax1, Shh, Ovo2, HBB and HIF were selected and qRT-PCR screening was performed on MSCs, ACs, NCs and NP cells cultured in hypoxic, low-glucose conditions with TGF $\beta 1$ supplementation. The markers Pax1, Shh and Ovo2 could not be detected in any cell type. Expression of $\mathrm{Krt18}, \mathrm{HBB}$ and HIF was similar in all four cell types as they displayed no trends or significant changes. Expression of Krt8, Krt19 and T was detected to a lower extend, if at all, in the three cell therapy sources as compared to NP cells. Overall, gene expression of all measured markers in the three cell sources was similar (no statistically significant variation), with the exception of the transcription factor FoxF1 (Fig. 7a). Further analysis of this marker in all the tested conditions showed that at $\mathrm{d} 0$ expression of FoxF1 was just above the level of detection in NCs and not detectable in ACs nor MSCs. After $28 \mathrm{~d}$ of pellet culture, NCs displayed a maintenance or a non-significant increase in FoxF1 gene expression in all conditions without TGF $\beta 1$ and standard, primed conditions (Fig. 7b). These data indicated that, in respect to the chosen markers, NCs cultured in micromass shared a joint marker with NP cells.

\section{Discussion}

MSCs are the cell source analysed most frequently in conditions resembling the environment of an IVD (Huang et al., 2013), as they are the most commonly used cell source for DDD cell therapy. However, most reports have only investigated one or two facets of the degenerating IVD. The presented work was the first to compare MSCs, ACs and NCs in identical conditions representing multiple physiological characteristics of the degenerated disc environment. The results showed that in hypoxic, low-glucose and growth-factor-free culture conditions, NCs were superior to both MSCs and ACs in survival, proliferation and reproducible ECM accumulation. In respect to MSC behaviour, results were consistent with previous studies (Kanichai et al., 2008; Risbud et al., 2004). Recently, Versicherla and Buckley (2017) have performed a similar study in which they have compared the performance of alginateencapsulated bovine NCs and ACs cultured with low-glucose medium in either normoxia or hypoxic $\left(5 \% \mathrm{O}_{2}\right)$ conditions with and without TGF 33 supplementation. In line with their growth factor-free results, the present study observations supported the eminence of NC capabilities in hypoxic, lowglucose conditions. Moreover, the degenerated disc environment has further harsh characteristics, such as acidity and inflammation. Cell potency could be increased through TGF $\beta$ supplementation. Although continuous TGF $\beta$ supplementation would not be foreseen in a therapeutical setting, a cell treatment could be initiated in combination with the delivery of growth factors. A follow-up experiment with chondrogenesis-primed cells in hypoxia, lowglucose, acidic and inflamed conditions indicated that NCs were more liable to reproducibly endure a degenerated IVD environment and accumulate ECM, as measured GAG levels were equal or higher than that of MSCs or ACs. Additionally, NCs were the only cell source to accumulate sufficient Col2 in standard, inflamed conditions to be detected by immunohistochemistry.

Despite these encouraging outcomes were in line with previous studies, it should not be neglected that ECM component values were not in the same range of magnitude as native tissue or previous studies. Cell therapy for treating DDD is mainly aimed at re-establishing the balance of anabolic and catabolic processes regulating NP matrix maintenance. It is logical to favour a cell source which can accumulate a similar, if not equal, amount of ECM as a healthy NP. Native healthy NP tissue has a unique biochemical composition with a GAG to collagen ratio of $27: 1$ (Mwale et al., 2004). For all three tested cell types, results generated under the described conditions did not come close to this ratio. GAG to collagen ratio was also not comparable to that measured by Vedicherla and Buckley (2017), who performed similar experiments with bovine ACs and NCs in alginate hydrogel. The use of hydrogels, scaffolds or micro-carriers, as well as the seeding density within such constructs, can influence cell re-differentiation and ECM accumulation (Lee et al., 2017; Miao et al., 2018). The aim of the present study was to compare the individual potency of the three cell sources independent of a scaffold material. IVD degeneration process is believed to be initiated by the dehydration of the NP caused by the reduced synthesis of GAG matrix. Cell concentration declines progressively, leading to further decline in matrix turnover, not just in the NP, but also in the annulus fibrosus, which becomes thickened and may develop radial fissures (Rea et al., 2012). Injection of cells that survive and accumulate cartilaginous matrix in the hostile IVD 
environment could slow down or even halt the progression of DDD and possibly its associated pain in patients diagnosed in early stages. It has not been proven that this matrix has to be analogous to that of a healthy NP tissue in terms of quality and abundance. It stands to reason that a divergent matrix accumulated and maintained by injected cells could inhibit disc height loss, compression stress on the annulus fibrosus and its thickening. Nonetheless, although the matrix produced by all three cells sources was more akin to hyaline or fibrocartilage, the matrix synthesised by NCs was still more similar to that of the NP than those synthesised by ACs and MSCs. Aside from their matrix-forming capacity, an increase in DNA content in NC constructs could be observed, which suggested their capability to proliferate even in a low-nutrient IVD environment. An increase in cell number is desirable to the extent where the proliferation of injected cells could compensate for the continued loss of native resident NP cells. In vivo investigations are planned to determine survival and proliferative capacity of NCs in an IVD, whether NC-accumulated matrix is sufficient to compensate for the loss of the actual NP tissue, and to ascertain whether the potential of NC matrix synthesis could be optimised with a suitable carrier material.

Although both NCs and ACs were committed chondrocytes and both survived in the harsh conditions better than MSCs, NCs displayed increased DNA content and ECM accumulation as compared to ACs. Mechanisms which could explain the differences between the two chondrocyte types are still unclear but could be related to the lack of peroxisome proliferator-activated receptor (PPAR) signalling in NCs, which restricts TGF $\beta$ signalling in ACs (do Amaral et al., 2012). The robustness of NCs has also been attributed to their developmental origin. Articular cartilage is a derivative of the mesoderm, whereas nasal cartilage derives from cranial neural crest stem cells, which are of neural ectoderm origin (Santagati and Rijli, 2003). Many studies have compared gene expression of ACs to NP cells to distinguish and identify NP-specific genotypic markers. The contribution and function of such markers to an NP phenotype remains unknown. However, it is speculated that they contribute to physiologic consequences and dictate NP cell function (Lv et al., 2014; Risbud et al., 2015; Rodrigues-Pinto et al., 2013). Due to the difference in developmental origin, it was conceivable that there would also be differences in the expression of some of these markers between NCs and ACs. The expression levels of these markers were similar in MSCs, ACs and NCs, with one exception. The transcription factor FoxF1 was detected in NCs but not in ACs or MSCs, thus establishing a genetic similarity to NP cells. The precise functions of FoxF1 are still unknown, but FoxF1 is a downstream target of hedgehog signalling and is involved in cell growth and ECM regulation in anti-fibrotic pathways (Melboucy-Belkhir et al., 2014).
It is tempting to speculate that FoxF1 contributed to the robustness required by NP cells to survive in the harsh IVD environment; however, this would need to be evaluated in further studies.

A preliminary attempt was taken at determining why ACs and NCs were less affected than MSCs by proinflammatory cytokines. An investigation of corresponding receptor gene expression did not lead to any conclusive finding. Nonetheless, NCs had an increased gene expression of TNF $\alpha R$ and IL1R1 in hypoxic, low-glucose, standard and non-inflamed conditions as compared to cells post-expansion. These levels were decreased in acidic and inflamed conditions. Thus, NCs had a different reaction to environmental cues on receptor expression than MSCs or ACs, which behaved similarly.

The most common cell source used in treating DDD by cell therapy is MSCs, due to their high proliferative ability, multilineage potential and immunomodulatory properties. However, MSCs also display many drawbacks, one of which is a wellknown donor variability (Eslaminejad et al., 2013; Kim et al., 2018). Such a variability was observed also in the present study, with respect to chondrogenic potential. Results indicated that, beyond inter-donor variability, one challenge when using MSCs in IVD regeneration is their capacity to react to harsh conditions mimicking the IVD environment. In fact, even the most chondrogenic MSCs consistently displayed weakened ability to synthesise ECM the harsher the environment became, up to the point of probable cell death in acidic medium. MSC vulnerability to the environment at the implantation site has been observed in various studies on different tissues (Degano et al., 2008; Haider and Ashraf, 2008; Logeart-Avramoglou et al., 2010; Togel et al., 2008). One of the harshest surroundings is found in the IVD, due to the IVD being the largest non-vascularised structure of the human body. Nevertheless, multiple clinical trials have attempted to inject MSCs into the disc with the purpose of tissue replacement, as MSCs are a convenient cell source (Sakai and Andersson, 2015). Neither tissue replacement nor residing viable injected cells could be demonstrated in these studies. Even so, patients of the previously mentioned trials described pain lessening. This effect, also witnessed in MSC clinical studies for other tissues, is increasingly attributed to the paracrine activity of MSCs, MSCmediated transfer of organelles, as well as the transfer of molecules through MSC-derived extra-cellular vesicles (Spees et al., 2016). These characteristics of MSCs have become so distinguishable to suggest the name of "Medicinal Signalling Cells" (Caplan, 2017). In this regard, the study aim was not to discourage MSC consideration for DDD treatment but imply that direct tissue replacement or regeneration is not to be expected. Moreover, function and effect of transplanted MSCs as therapeutic drug delivery in situ through their exchange of bioactive factors need to be considered. Since this aspect was not within the scope of the study, further work will be necessary 
to compare the potency of the different cell sources related to paracrine conditioning as an alternative mode of action.

Previous studies have explored the chondrogenic capacity of MSCs and ACs and found that committed chondrocytes are more adept at making stable cartilaginous tissue (Acosta et al., 2011; Erickson et al., 2009; Fernandes et al., 2013; Kuh et al., 2009; Tew et al., 2008). These findings would make ACs the preferable source for cell therapy of joint-related orthopaedic malignancies such as DDD and osteoarthritis. However, considering that to obtain autologous ACs, a biopsy of a healthy joint is required, which may initiate a degeneration in the respective joint, autologous ACs are less than ideal candidates. In addition, extensive laboratory-based expansion leads to dedifferentiation, which in turn requires growth factor supplementation to maintain or restore the AC phenotype (Gruber et al., 1997). NCs, on the other hand, can be relatively effortlessly acquired from the septal cartilage under local anaesthetic without negative consequences to the source structure or donor site morbidity. Furthermore, NCs have improved capacity for ECM deposition as compared to AC in articular joint settings (Candrian et al., 2008; Kafienah et al., 2002; Pelttari et al., 2014; Scotti et al., 2012). These findings and many others validating NCs for tissue-engineered cartilage constructs (Asawa et al., 2009; Chia et al., 2005; Fulco et al., 2014; Hellingman et al., 2011; Malda et al., 2004; Reuther et al., 2014; Richmon et al., 2005; Twu et al., 2014; Watson and Reuther, 2014) have aroused the interest to consider NCs for NP tissue regeneration (Tsaryk et al., 2015; Tsaryk et al., 2017).

This was the first study to compare NCs to MSCs and ACs, which are presently being tested in clinical trials, in respect to their ECM-forming capacity under conditions modelled after a degenerated disc environment, as these are well known. NCs seemed to be a better choice for treatment of DDD than MSCs and ACs, as they could better produce ECM in an in vitro IVD environment, are easily attainable and have a good proliferative capacity. The study findings encourage the assessment of NCs in a cell therapy treatment of DDD to promote new matrix production in the IVD, which could inhibit or delay further IVD height loss if not even lead to height gain and repair. As this application was only recently recognised in this study, in vitro, in vivo characterisation of their performance in a degenerated disc environment is crucial.

\section{References}

Acosta FL, Jr., Metz L, Adkisson HD, Liu J, Carruthers-Liebenberg E, Milliman C, Maloney M, Lotz JC (2011) Porcine intervertebral disc repair using allogeneic juvenile articular chondrocytes or mesenchymal stem cells. Tissue Eng Part A 17: 30453055.
Adams MA, Roughley PJ (2006) What is intervertebral disc degeneration, and what causes it? Spine (Phila Pa 1976) 31: 2151-2161.

Akyol S, Eraslan BS, Etyemez H, Tanriverdi T, Hanci M (2010) Catabolic cytokine expressions in patients with degenerative disc disease. Turk Neurosurg 20: 492-499.

Altun I (2016) Cytokine profile in degenerated painful intervertebral disc: variability with respect to duration of symptoms and type of disease. Spine J 16: 857-861.

Asawa Y, Ogasawara T, Takahashi T, Yamaoka H, Nishizawa S, Matsudaira K, Mori Y, Takato T, Hoshi K (2009) Aptitude of auricular and nasoseptal chondrocytes cultured under a monolayer or three-dimensional condition for cartilage tissue engineering. Tissue Eng Part A 15: 1109-1118.

Barbero A, Grogan SP, Mainil-Varlet P, Martin I (2006) Expansion on specific substrates regulates the phenotype and differentiation capacity of human articular chondrocytes. J Cell Biochem 98: 1140-1149.

Barbero A, Ploegert S, Heberer M, Martin I (2003) Plasticity of clonal populations of dedifferentiated adult human articular chondrocytes. Arthritis Rheum 48: 1315-1325.

Barbosa I, Garcia S, Barbier-Chassefiere V, Caruelle JP, Martelly I, Papy-Garcia D (2003) Improved and simple micro assay for sulfated glycosaminoglycans quantification in biological extracts and its use in skin and muscle tissue studies. Glycobiology 13: 647-653.

Candrian C, Vonwil D, Barbero A, Bonacina E, Miot S, Farhadi J, Wirz D, Dickinson S, Hollander A, Jakob M, Li Z, Alini M, Heberer M, Martin I (2008) Engineered cartilage generated by nasal chondrocytes is responsive to physical forces resembling joint loading. Arthritis Rheum 58: 197-208.

Caplan AI (2017) Mesenchymal stem cells: time to change the name! Stem Cells Transl Med 6: 1445-1451.

Capossela S, Bertolo A, Gunasekera K, Potzel T, Baur M, Stoyanov JV (2018) VEGF vascularization pathway in human intervertebral disc does not change during the disc degeneration process. BMC Res Notes 11: 333. DOI: 10.1186/s13104-018-3441-3.

Chia SH, Homicz MR, Schumacher BL, Thonar EJ, Masuda K, Sah RL, Watson D (2005) Characterization of human nasal septal chondrocytes cultured in alginate. J Am Coll Surg 200: 691-704.

de Schepper EI, Damen J, van Meurs JB, Ginai AZ, Popham M, Hofman A, Koes BW, Bierma-Zeinstra SM (2010) The association between lumbar disc degeneration and low back pain: the influence of age, gender, and individual radiographic features. Spine (Phila Pa 1976) 35: 531-536.

Degano IR, Vilalta M, Bago JR, Matthies AM, Hubbell JA, Dimitriou H, Bianco P, Rubio N, Blanco $\mathrm{J}$ (2008) Bioluminescence imaging of calvarial bone repair using bone marrow and adipose tissue-derived mesenchymal stem cells. Biomaterials 29: 427-437.

do Amaral RJ, Pedrosa Cda S, Kochem MC, Silva KR, Aniceto M, Claudio-da-Silva C, Borojevic R, Baptista LS (2012) Isolation of human nasoseptal 
chondrogenic cells: a promise for cartilage engineering. Stem Cell Res 8: 292-299.

Erickson IE, Huang AH, Chung C, Li RT, Burdick JA, Mauck RL (2009) Differential maturation and structure-function relationships in mesenchymal stem cell- and chondrocyte-seeded hydrogels. Tissue Eng Part A 15: 1041-1052.

Eslaminejad MB, Fani N, Shahhoseini M (2013) Epigenetic regulation of osteogenic and chondrogenic differentiation of mesenchymal stem cells in culture. Cell J 15: 1-10.

Fernandes AM, Herlofsen SR, Karlsen TA, Kuchler AM, Floisand Y, Brinchmann JE (2013) Similar properties of chondrocytes from osteoarthritis joints and mesenchymal stem cells from healthy donors for tissue engineering of articular cartilage. PLoS One 8: e62994. DOI: 10.1371/journal.pone.0062994.

Frank O, Heim M, Jakob M, Barbero A, Schafer D, Bendik I, Dick W, Heberer M, Martin I (2002) Real-time quantitative RT-PCR analysis of human bone marrow stromal cells during osteogenic differentiation in vitro. J Cell Biochem 85: 737-746.

Fulco I, Miot S, Haug MD, Barbero A, Wixmerten A, Feliciano S, Wolf F, Jundt G, Marsano A, Farhadi J, Heberer M, Jakob M, Schaefer DJ, Martin I (2014) Engineered autologous cartilage tissue for nasal reconstruction after tumour resection: an observational first-in-human trial. Lancet 384: 337346.

Gilbert HT, Hodson N, Baird P, Richardson SM, Hoyland JA (2016) Acidic $\mathrm{pH}$ promotes intervertebral disc degeneration: acid-sensing ion channel -3 as a potential therapeutic target. Sci Rep 6: 37360. DOI: 10.1038/srep37360.

Grogan SP, Barbero A, Winkelmann V, Rieser F, Fitzsimmons JS, O’Driscoll S, Martin I, Mainil-Varlet P (2006) Visual histological grading system for the evaluation of in vitro-generated neocartilage. Tissue Eng 12: 2141-2149.

Gruber HE, Stasky AA, Hanley EN, Jr. (1997) Characterization and phenotypic stability of human disc cells in vitro. Matrix Biol 16: 285-288.

Haider H, Ashraf M (2008) Strategies to promote donor cell survival: combining preconditioning approach with stem cell transplantation. J Mol Cell Cardiol 45: 554-566.

Hellingman CA, Verwiel ET, Slagt I, Koevoet W, Poublon RM, Nolst-Trenite GJ, Baatenburg de Jong RJ, Jahr H, van Osch GJ (2011) Differences in cartilageforming capacity of expanded human chondrocytes from ear and nose and their gene expression profiles. Cell Transplant 20: 925-940.

Huang YC, Leung VY, Lu WW, Luk KD (2013) The effects of microenvironment in mesenchymal stem cell-based regeneration of intervertebral disc. Spine J 13: 352-362.

Huang YC, Urban JP, Luk KD (2014) Intervertebral disc regeneration: do nutrients lead the way? Nat Rev Rheumatol 10: 561-566.

Ichimura K, Tsuji H, Matsui H, Makiyama N (1991) Cell culture of the intervertebral disc of rats: factors influencing culture, proteoglycan, collagen, and deoxyribonucleic acid synthesis. J Spinal Disord 4: 428-436.

Johnson ZI, Schoepflin ZR, Choi H, Shapiro IM, Risbud MV (2015) Disc in flames: roles of TNF-alpha and IL-1beta in intervertebral disc degeneration. Eur Cell Mater 30: 104-116.

Kafienah W, Jakob M, Demarteau O, Frazer A, Barker MD, Martin I, Hollander AP (2002) Threedimensional tissue engineering of hyaline cartilage: comparison of adult nasal and articular chondrocytes. Tissue Eng 8: 817-826.

Kanichai M, Ferguson D, Prendergast PJ, Campbell VA (2008) Hypoxia promotes chondrogenesis in rat mesenchymal stem cells: a role for AKT and hypoxiainducible factor (HIF)-1alpha. J Cell Physiol 216: 708-715.

Kim M, Erickson IE, Huang AH, Garrity ST, Mauck RL, Steinberg DR (2018) Donor variation and optimization of human mesenchymal stem cell chondrogenesis in hyaluronic acid. Tissue Eng Part A 24: 1693-1703.

Kuh SU, Zhu Y, Li J, Tsai KJ, Fei Q, Hutton WC, Yoon TS (2009) A comparison of three cell types as potential candidates for intervertebral disc therapy: annulus fibrosus cells, chondrocytes, and bone marrow derived cells. Joint Bone Spine 76: 70-74.

Lee HP, Gu L, Mooney DJ, Levenston ME, Chaudhuri O (2017) Mechanical confinement regulates cartilage matrix formation by chondrocytes. Nat Mater 16: 1243-1251.

Logeart-Avramoglou D, Oudina K, Bourguignon M, Delpierre L, Nicola MA, Bensidhoum M, Arnaud E, Petite H (2010) In vitro and in vivo bioluminescent quantification of viable stem cells in engineered constructs. Tissue Eng Part C Methods 16: 447-458.

Luoma K, Riihimaki H, Luukkonen R, Raininko R, Viikari-Juntura E, Lamminen A (2000) Low back pain in relation to lumbar disc degeneration. Spine (Phila Pa 1976) 25: 487-492.

Lv F, Leung VY, Huang S, Huang Y, Sun Y, Cheung KM (2014) In search of nucleus pulposusspecific molecular markers. Rheumatology (Oxford) 53: 600-610.

Malda J, van Blitterswijk CA, van Geffen M, Martens DE, Tramper J, Riesle J (2004) Low oxygen tension stimulates the redifferentiation of dedifferentiated adult human nasal chondrocytes. Osteoarthritis Cartilage 12: 306-313.

Melboucy-Belkhir S, Pradere P, Tadbiri S, Habib S, Bacrot A, Brayer S, Mari B, Besnard V, Mailleux A, Guenther A, Castier Y, Mal H, Crestani B, Plantier L (2014) Forkhead Box F1 represses cell growth and inhibits COL1 and ARPC2 expression in lung fibroblasts in vitro. Am J Physiol Lung Cell Mol Physiol 307: L838-847.

Miao Z, Lu Z, Wu H, Liu H, Li M, Lei D, Zheng L, Zhao J (2018) Collagen, agarose, alginate, and Matrigel hydrogels as cell substrates for culture of chondrocytes in vitro: a comparative study. J Cell Biochem 119: 7924-7933. 
Molinos M, Almeida CR, Caldeira J, Cunha C, Goncalves RM, Barbosa MA (2015) Inflammation in intervertebral disc degeneration and regeneration. J R Soc Interface 12: 20150429. DOI: 10.1098/ rsif.2015.0429.

Muller AM, Davenport M, Verrier S, Droeser R, Alini M, Bocelli-Tyndall C, Schaefer DJ, Martin I, Scherberich A (2009) Platelet lysate as a serum substitute for 2D static and 3D perfusion culture of stromal vascular fraction cells from human adipose tissue. Tissue Eng Part A 15: 869-875.

Muller S, Acevedo L, Wang X, Karim MZ, Matta A, Mehrkens A, Schaeren S, Feliciano S, Jakob M, Martin I, Barbero A, Erwin WM (2016) Notochordal cell conditioned medium (NCCM) regenerates endstage human osteoarthritic articular chondrocytes and promotes a healthy phenotype. Arthritis Res Ther 18: 125. DOI: 10.1186/s13075-016-1026-x.

Mumme M, Barbero A, Miot S, Wixmerten A, Feliciano S, Wolf F, Asnaghi AM, Baumhoer D, Bieri O, Kretzschmar M, Pagenstert G, Haug M, Schaefer DJ, Martin I, Jakob M (2016) Nasal chondrocyte-based engineered autologous cartilage tissue for repair of articular cartilage defects: an observational first-inhuman trial. Lancet 388: 1985-1994.

Mwale F, Roughley P, Antoniou J (2004) Distinction between the extracellular matrix of the nucleus pulposus and hyaline cartilage: a requisite for tissue engineering of intervertebral disc. Eur Cell Mater 8: 58-63.

Naqvi SM, Buckley CT (2016) Bone marrow stem cells in response to intervertebral disc-like matrix acidity and oxygen concentration: implications for cell-based regenerative therapy. Spine (Phila Pa 1976) 41: 743-750.

Pelttari K, Pippenger B, Mumme M, Feliciano S, Scotti C, Mainil-Varlet P, Procino A, von Rechenberg B, Schwamborn T, Jakob M, Cillo C, Barbero A, Martin I (2014) Adult human neural crest-derived cells for articular cartilage repair. Sci Transl Med 6: 251ra119. DOI: 10.1126/scitranslmed.3009688.

Pennicooke B, Moriguchi Y, Hussain I, Bonssar L, Hartl R (2016) Biological treatment approaches for degenerative disc disease: a review of clinical trials and future directions. Cureus 8: e892. DOI: 10.7759/ cureus.892.

Pfirrmann CW, Metzdorf A, Zanetti M, Hodler J, Boos N (2001) Magnetic resonance classification of lumbar intervertebral disc degeneration. Spine 26: 1873-1878.

Rea W, Kapur S, Mutagi H (2012) Intervertebral disc as a source of pain. Continuing Education in Anaesthesia Critical Care \& Pain 12: 279-282.

Reuther MS, Briggs KK, Neuman MK, Masuda K, Sah RL, Watson D (2014) Volume expansion of tissue engineered human nasal septal cartilage. J Otol Rhinol 3. DOI: 10.4172/2324-8785.1000172

Richmon JD, Sage AB, Shelton E, Schumacher BL, Sah RL, Watson D (2005) Effect of growth factors on cell proliferation, matrix deposition, and morphology of human nasal septal chondrocytes cultured in monolayer. Laryngoscope 115: 1553-1560.

Risbud MV, Albert TJ, Guttapalli A, Vresilovic EJ, Hillibrand AS, Vaccaro AR, Shapiro IM (2004) Differentiation of mesenchymal stem cells towards a nucleus pulposus-like phenotype in vitro: implications for cell-based transplantation therapy. Spine (Phila Pa 1976) 29: 2627-2632.

Risbud MV, Schoepflin ZR, Mwale F, Kandel RA, Grad S, Iatridis JC, Sakai D, Hoyland JA (2015) Defining the phenotype of young healthy nucleus pulposus cells: recommendations of the Spine Research Interest Group at the 2014 annual ORS meeting. J Orthop Res 33: 283-293.

Risbud MV, Shapiro IM (2014) Role of cytokines in intervertebral disc degeneration: pain and disc content. Nat Rev Rheumatol 10: 44-56.

Roberts S, Evans H, Trivedi J, Menage J (2006) Histology and pathology of the human intervertebral disc. J Bone Joint Surg Am 88 Suppl 2: 10-14.

Rodrigues-Pinto R, Richardson SM, Hoyland JA (2013) Identification of novel nucleus pulposus markers: Interspecies variations and implications for cell-based therapies for intervertebral disc degeneration. Bone Joint Res 2: 169-178.

Sakai D, Andersson GB (2015) Stem cell therapy for intervertebral disc regeneration: obstacles and solutions. Nat Rev Rheumatol 11: 243-256.

Santagati F, Rijli FM (2003) Cranial neural crest and the building of the vertebrate head. Nat Rev Neurosci 4: 806-818.

Scotti C, Osmokrovic A, Wolf F, Miot S, Peretti GM, Barbero A, Martin I (2012) Response of human engineered cartilage based on articular or nasal chondrocytes to interleukin-1beta and low oxygen. Tissue Eng Part A 18: 362-372.

Siepe CJ, Heider F, Wiechert K, Hitzl W, Ishak B, Mayer MH (2014) Mid- to long-term results of total lumbar disc replacement: a prospective analysis with 5- to 10-year follow-up. Spine J 14: 1417-1431.

Sivan SS, Hayes AJ, Wachtel E, Caterson B, Merkher Y, Maroudas A, Brown S, Roberts S (2014) Biochemical composition and turnover of the extracellular matrix of the normal and degenerate intervertebral disc. Eur Spine J 23 Suppl 3: S344-353.

Spees JL, Lee RH, Gregory CA (2016) Mechanisms of mesenchymal stem/stromal cell function. Stem Cell Res Ther 7: 125. DOI: 10.1186/s13287-016-0363-7.

Tew SR, Murdoch AD, Rauchenberg RP, Hardingham TE (2008) Cellular methods in cartilage research: primary human chondrocytes in culture and chondrogenesis in human bone marrow stem cells. Methods 45: 2-9.

Togel F, Yang Y, Zhang P, Hu Z, Westenfelder C (2008) Bioluminescence imaging to monitor the in vivo distribution of administered mesenchymal stem cells in acute kidney injury. Am J Physiol Renal Physiol 295: F315-321.

Tsaryk R, Gloria A, Russo T, Anspach L, De Santis R, Ghanaati S, Unger RE, Ambrosio L, Kirkpatrick 
CJ (2015) Collagen-low molecular weight hyaluronic acid semi-interpenetrating network loaded with gelatin microspheres for cell and growth factor delivery for nucleus pulposus regeneration. Acta Biomater 20: 10-21.

Tsaryk R, Silva-Correia J, Oliveira JM, Unger RE, Landes C, Brochhausen C, Ghanaati S, Reis RL, Kirkpatrick CJ (2017) Biological performance of cell-encapsulated methacrylated gellan gum-based hydrogels for nucleus pulposus regeneration. J Tissue Eng Regen Med 11: 637-648.

Twu CW, Reuther MS, Briggs KK, Sah RL, Masuda K, Watson D (2014) Effect of oxygen tension on tissueengineered human nasal septal chondrocytes. Allergy Rhinol (Providence) 5: 125-131.

Urban JP (2002) The role of the physicochemical environment in determining disc cell behaviour. Biochem Soc Trans 30: 858-864.

Vedicherla S, Buckley CT (2017) In vitro extracellular matrix accumulation of nasal and articular chondrocytes for intervertebral disc repair. Tissue Cell 49: 503-513.

Vos T, Flaxman AD, Naghavi M, Lozano R, Michaud C, Ezzati M, Shibuya K, Salomon JA, Abdalla S, Aboyans V, Abraham J, Ackerman I, Aggarwal R, Ahn SY, Ali MK, Alvarado M, Anderson HR, Anderson LM, Andrews KG, Atkinson C, Baddour LM, Bahalim AN, Barker-Collo S, Barrero LH, Bartels DH, Basanez MG, Baxter A, Bell ML, Benjamin EJ, Bennett D, Bernabe E, Bhalla K, Bhandari B, Bikbov B, Bin Abdulhak A, Birbeck G, Black JA, Blencowe H, Blore JD, Blyth F, Bolliger I, Bonaventure A, Boufous S, Bourne R, Boussinesq M, Braithwaite T, Brayne C, Bridgett L, Brooker S, Brooks P, Brugha TS, Bryan-Hancock C, Bucello C, Buchbinder R, Buckle G, Budke CM, Burch M, Burney P, Burstein R, Calabria B, Campbell B, Canter CE, Carabin H, Carapetis J, Carmona L, Cella C, Charlson F, Chen H, Cheng AT, Chou D, Chugh SS, Coffeng LE, Colan SD, Colquhoun $\mathrm{S}$, Colson KE, Condon J, Connor MD, Cooper LT, Corriere M, Cortinovis $\mathrm{M}$, de Vaccaro KC, Couser W, Cowie BC, Criqui MH, Cross M, Dabhadkar KC, Dahiya M, Dahodwala N, Damsere-Derry J, Danaei G, Davis A, De Leo D, Degenhardt L, Dellavalle R, Delossantos A, Denenberg J, Derrett S, Des Jarlais DC, Dharmaratne SD, Dherani M, Diaz-Torne C, Dolk H, Dorsey ER, Driscoll T, Duber H, Ebel B, Edmond K, Elbaz A, Ali SE, Erskine H, Erwin PJ, Espindola P, Ewoigbokhan SE, Farzadfar F, Feigin V, Felson DT, Ferrari A, Ferri CP, Fevre EM, Finucane MM, Flaxman S, Flood L, Foreman K, Forouzanfar $\mathrm{MH}$, Fowkes FG, Franklin R, Fransen M, Freeman MK, Gabbe BJ, Gabriel SE, Gakidou E, Ganatra HA, Garcia B, Gaspari F, Gillum RF, Gmel G, Gosselin R, Grainger R, Groeger J, Guillemin F, Gunnell D, Gupta R, Haagsma J, Hagan H, Halasa YA, Hall W, Haring D, Haro JM, Harrison JE, Havmoeller R, Hay RJ, Higashi H, Hill C, Hoen B, Hoffman H, Hotez PJ, Hoy D, Huang JJ, Ibeanusi SE, Jacobsen KH, James SL, Jarvis D, Jasrasaria R, Jayaraman S, Johns N, Jonas JB,
Karthikeyan G, Kassebaum N, Kawakami N, Keren A, Khoo JP, King CH, Knowlton LM, Kobusingye O, Koranteng A, Krishnamurthi R, Lalloo R, Laslett LL, Lathlean T, Leasher JL, Lee YY, Leigh J, Lim SS, Limb E, Lin JK, Lipnick M, Lipshultz SE, Liu W, Loane M, Ohno SL, Lyons R, Ma J, Mabweijano J, MacIntyre MF, Malekzadeh R, Mallinger L, Manivannan S, Marcenes W, March L, Margolis DJ, Marks GB, Marks R, Matsumori A, Matzopoulos R, Mayosi BM, McAnulty JH, McDermott MM, McGill N, McGrath J, MedinaMora ME, Meltzer M, Mensah GA, Merriman TR, Meyer AC, Miglioli V, Miller M, Miller TR, Mitchell PB, Mocumbi AO, Moffitt TE, Mokdad AA, Monasta L, Montico M, Moradi-Lakeh M, Moran A, Morawska L, Mori R, Murdoch ME, Mwaniki MK, Naidoo K, Nair MN, Naldi L, Narayan KM, Nelson PK, Nelson RG, Nevitt MC, Newton CR, Nolte S, Norman P, Norman R, O'Donnell M, O'Hanlon S, Olives C, Omer SB, Ortblad K, Osborne R, Ozgediz D, Page A, Pahari B, Pandian JD, Rivero AP, Patten SB, Pearce N, Padilla RP, Perez-Ruiz F, Perico N, Pesudovs K, Phillips D, Phillips MR, Pierce K, Pion S, Polanczyk GV, Polinder S, Pope CA, 3rd, Popova S, Porrini E, Pourmalek F, Prince M, Pullan RL, Ramaiah KD, Ranganathan D, Razavi H, Regan M, Rehm JT, Rein DB, Remuzzi G, Richardson K, Rivara FP, Roberts T, Robinson C, De Leon FR, Ronfani L, Room R, Rosenfeld LC, Rushton L, Sacco RL, Saha S, Sampson U, Sanchez-Riera L, Sanman E, Schwebel DC, Scott JG, Segui-Gomez M, Shahraz S, Shepard DS, Shin H, Shivakoti R, Singh D, Singh GM, Singh JA, Singleton J, Sleet DA, Sliwa K, Smith E, Smith JL, Stapelberg NJ, Steer A, Steiner T, Stolk WA, Stovner LJ, Sudfeld C, Syed S, Tamburlini G, Tavakkoli M, Taylor HR, Taylor JA, Taylor WJ, Thomas B, Thomson WM, Thurston GD, Tleyjeh IM, Tonelli M, Towbin JA, Truelsen T, Tsilimbaris MK, Ubeda C, Undurraga EA, van der Werf MJ, van Os J, Vavilala MS, Venketasubramanian N, Wang M, Wang W, Watt K, Weatherall DJ, Weinstock MA, Weintraub R, Weisskopf MG, Weissman MM, White RA, Whiteford $\mathrm{H}$, Wiersma ST, Wilkinson JD, Williams HC, Williams SR, Witt E, Wolfe F, Woolf AD, Wulf S, Yeh PH, Zaidi AK, Zheng ZJ, Zonies D, Lopez AD, Murray CJ, AlMazroa MA, Memish ZA (2012) Years lived with disability (YLDs) for 1160 sequelae of 289 diseases and injuries 1990-2010: a systematic analysis for the Global Burden of Disease Study 2010. Lancet 380: 2163-2196.

Watson D, Reuther MS (2014) Tissue-engineered cartilage for facial plastic surgery. Curr Opin Otolaryngol Head Neck Surg 22: 300-306.

\section{Discussion with Reviewers}

Laura Creemers: In the proposed clinical application, would the number of cells isolated from the septum be sufficient for regeneration of an entire NP and to what extent could donor septum be considered?

Authors: Previous clinical trials (Fulco et al., 2014; 
Mumme et al., 2016) using biopsies from nasal septum for cartilage repair have shown that more than 50 million of nasal chondrocytes can be reproducibly generated after 2 weeks of expansion under condition similar to the one used in the present study. If around 10 million MSCs would be injected in a clinical trial, the cell number obtained would be sufficient. Nonetheless, the number of cells to be injected is still under consideration and is to be more closely determined in future projects.

Fakson Mwale: The IVD degenerative niches are unlikely to support increased cell numbers due to nutritional demands. How do the authors plan to address this problem?

Authors: To mimic this specific characterisation, lowglucose media (as found in a degenerated IVD) was used. In these conditions NCs showed to be more robust as compared to ACs and MSCs. Nonetheless, addition of other growth factors, besides TGF $\beta 1$, are being considered and evaluated, which could boost the potency of the NCs to survive and even proliferate in a low-nutrition environment.

Fakson Mwale: What did in the results suggest that what was being formed was a disc (NP, annulus fibrosus or endplate) phenotype?

Authors: The aim of the study was not to create a complete analogous NP phenotype with cells. For cell therapy of the disc, cells need to survive in harsh conditions and be able to accumulate an ECM. Of course, it would be ideal if the matrix was as close as possible to the healthy NP matrix. NCs accumulated a matrix closer to the NP tissue (at least as far as GAG accumulation is concerned) than either MSCs or ACs, which are currently used in trials. If hyaline cartilage or fibrocartilage are sufficient to maintain disc height and prevent further degeneration of the annulus fibrosus has to be determined in vivo.

Fakson Mwale: Why is the cell phenotype an advantage in an environment that lucks nutrition?

Authors: All the cells were cultured in low-glucose medium to determine the effects of a nutritionlacking environment. ACs and NCs were not distinctly affected by this change as compared to MSCs. Moreover, if injected cells could survive and create matrix, even if not completely in conformity with the NP tissue, this could lead to a rescue of disc height loss and inhibit radial fissures in the annulus fibrosus due to compression stress.

Fakson Mwale: How do pellet cultures mimic the disc cell environment?

Authors: Pellet culture does not mimic the disc phenotype. However, it represents the preferential system to model and induce chondrogenesis. For this reason, it was used to assess cell response to IVD physiological characteristics, in terms of survival, proliferation and matrix production.

Fakson Mwale: Since there is not always a direct correlation between back pain and disc degeneration, how do the authors plan to identify good candidates? Authors: Our aim is to treat patients that have pain due to disc degeneration. There are cases of patients, who display disc degeneration but do not have pain. Candidates can first be identified when they come to the hospital because of pain. In some cases, this pain can be treated with conservative therapy; however, if the patient does to respond to therapy, can be considered for further treatment.

In an ethics proposal for a phase 1 clinical trial, the following inclusion criteria were established: any person suffering from persistent lower back pain [visual analogue scale (VAS) at least 50 (scale: 0-100)] since at least 6 months, which can be led back to degenerative disc disease (modified Pfirrman grade 4-6) on a single level, may be able to participate. The patient must also be unresponsive to conservative management (i.e. physiotherapy) for at least 3 months. Excluded are patients with a disc herniation or a spinal stenosis.

James Dennis: These cell preparations are expected to contribute to load-bearing in the spine. Have the authors examined the biomechanical properties of these tissues?

Authors: The mechanical loading of pellets is difficult. For this reason, the biomechanical properties in this setup were not tested. However, this is planned for future work in which a carrier system is determined and utilised.

Beyond the biomechanical properties of NCderived tissues, which have been previously addressed (Farhadi et al., 2006, additional reference), the authors consider highly relevant the response of the cells to mechanical stimulation. Previous work (Candrian et al., 2008) has shown that NCs-generated matrix would be adept in load response.

\section{Additional Reference}

Farhadi J, Fulco I, Miot S, Wirz D, Haug M, Dickinson SC, Hollander AP, Daniels AU, Pierer G, Heberer M, Martin I (2006) Precultivation of engineered human nasal cartilage enhances the mechanical properties relevant for use in facial reconstructive surgery. Ann Surg 244: 978-985.

Editor's note: The Scientific Editor responsible for this paper was Brian Johnstone. 